Nat. Hazards Earth Syst. Sci., 21, 683-701, 2021

https://doi.org/10.5194/nhess-21-683-2021

(C) Author(s) 2021. This work is distributed under the Creative Commons Attribution 4.0 License.

\title{
Radar-based assessment of hail frequency in Europe
}

\author{
Elody Fluck ${ }^{1, a}$, Michael Kunz ${ }^{1,2}$, Peter Geissbuehler ${ }^{3}$, and Stefan P. Ritz ${ }^{3}$ \\ ${ }^{1}$ Institute of Meteorology and Climate Research (IMK), Karlsruhe Institute of Technology (KIT), Karlsruhe, Germany \\ ${ }^{2}$ Center for Disaster Management and Risk Reduction Technology (CEDIM), Karlsruhe, Germany \\ ${ }^{3}$ RenaissanceRe Risk Sciences, Zurich, Switzerland \\ ${ }^{a}$ now at: Department of Earth and Planetary Sciences, Weizmann Institute of Science, Rehovot, Israel
}

Correspondence: Elody Fluck (elody.fluck@weizmann.ac.il)

Received: 23 April 2020 - Discussion started: 3 June 2020

Revised: 11 January 2021 - Accepted: 14 January 2021 - Published: 17 February 2021

\begin{abstract}
In this study we present a unique 10 year climatology of severe convective storm tracks for a large European area covering Germany, France, Belgium and Luxembourg. For the period 2005-2014, a high-resolution hail potential composite of $1 \times 1 \mathrm{~km}^{2}$ is produced from two-dimensional radar reflectivity and lightning data. Individual hailstorm tracks as well as their physical properties, such as radar reflectivity along the tracks, were reconstructed for the entire time period using the Convective Cell Tracking Algorithm (CCTA2D).

A sea-to-continent gradient in the number of hail days per year is found to be present over the whole domain. In addition, the highest number of severe storms is found on the leeward side of low mountain ranges such as the Massif Central in France and the Swabian Jura in southwest Germany. A latitude shift in the hail peak month is observed between the northern part of Germany, where hail occurs most frequently in August, and southern France, where the maximum amount of hail is 2 months earlier. The longest footprints with high reflectivity values occurred on 9 June 2014 and on 28 July 2013 with lengths reaching up to $500 \mathrm{~km}$. Both events were associated with hailstones measuring up to $10 \mathrm{~cm}$ diameter, which caused damage in excess of EUR 2 billion.
\end{abstract}

\section{Introduction}

Severe convective storms (SCSs) and their related hail constitute a major atmospheric hazard. These events have the potential to cause substantial damage to hail-susceptible objects such as buildings, crops or automobiles in various parts of Europe, including France, Germany, Austria and Switzer- land (e.g., Dessens, 1986; Puskeiler et al., 2016; Nisi et al., 2016). Prominent examples are the two hailstorms related to the low-pressure system Andreas that occurred on 2728 July 2013 over central and southern Germany with total economic losses estimated at approximately EUR 3.6 billion (SwissRe, 2014; Kunz et al., 2018). Hail occurs in organized convective storms (Auer, 1972), that is, multicells, supercells or mesoscale convective storms (Markowski and Richardson, 2010). Hail can also be produced by single-cell pulse storms; however, large hail is almost always associated with organized convection, particularly supercells (Smith et al., 2012; Wapler et al., 2016), and results from the interaction between diverse processes and mechanisms on different spatiotemporal scales. Several authors have studied environmental conditions favoring hail production (Dessens, 1986; Houze, 2014; Kunz et al., 2020, among others). In general, a subtle interplay between three main ingredients supports the formation of deep moist convection (Kunz, 2007): (1) conditional instability is needed for lifted parcels of air to become positively buoyant (2) a high moisture content in lower atmospheric levels lowers the level of free convection (LFC) in a cloud and increases convective available potential energy (CAPE) and (3) a lifting mechanism to trigger convection such as orographic lifting (Kirshbaum et al., 2018; Barthlott et al., 2016) or lifting associate with synoptic cold fronts (Kunz et al., 2020). Vertical wind shear is another parameter mainly relevant for the organization form of the storm and, thus, also for its lifetime and severity. Several authors have found that large hail preferably occurs in strongly sheared environments, supporting the formation of supercells (Brooks et al., 2003; Johnson and Sugden, 2014; Taszarek et al., 2017; Kunz et al., 2020; Pilorz and Łupikasza, 2020). Aside from 
the parameters mentioned above, some authors have found that an increased frequency of SCSs in Europe can be associated with specific large-scale flows or teleconnection patterns (Piper et al., 2019; Mohr et al., 2019; Kunz et al., 2020). Several authors found, for example, a configuration where the east of the Atlantic basin is dominated by a low pressure area and where France lies under a ridge (Piper et al., 2019; Fluck, 2018).

A major obstacle when investigating hail events and their climatology is the lack of accurate and comprehensive observations. This observation deficit is because of the localscale nature of SCSs and the even smaller hailstreaks with a small spatial extent (Changnon, 1977). There are only some high-density, regional-scale, ground-detection networks using hailpads for recording hail fall in operation, such as in southwestern and central France (Dessens, 1986; Vinet, 2001), parts of Spain (Fraile et al., 1992) and northern Italy (Eccel et al., 2012). The majority of Europe, however, remains uncovered by a hail network, leading to a gap in direct hail observations. Therefore, little is known about the localscale hail probability and related hail risk across Europe.

Numerous authors have used hail signals derived from conventional weather radars for the identification and analysis of hail because of their high temporal and spatial resolutions. For example, Nisi et al. $(2016,2018)$ established a hail climatology for Switzerland from 2002 to 2014 based on both the probability of hail $(\mathrm{POH})$ and maximum expected severe hail size (MESHS) estimated from volumetric (3D) radar data. Puskeiler et al. (2016) used 3D radar reflectivity together with modeled melting layer, lightning data and the cell-tracking algorithm TRACE3D (Handwerker, 2002) to reconstruct hailstreaks and, from that, to estimate the hail frequency across Germany between 2005 and 2011. By combining 3D radar reflectivity and insurance loss data for buildings, Kunz and Puskeiler (2010) it was found that the highest hail frequency in southwest Germany is located downstream of the Black Forest mountains. This hotspot was also confirmed by Kunz and Kugel (2015) using five different hail criteria based on 2D and 3D radar reflectivities and different heights (melting layer, echo top). Lukach et al. (2017) computed a hail frequency map for Belgium from 2003 to 2012 using 3D radar data. Outside of Europe, Cintineo et al. (2012) produced a high-resolution hail frequency map for the USA from 2007 to 2010 using MESH (Maximum Expected Size of Hail) product. The authors found a high hail frequency during March to September (with June as a maximum) in the Great Plains. More precisely, the highest hail frequency is mainly centered over the southern part of the Great Plains from March until May, while from July to September hail is more frequent in the central and northern plains. The MESH product was also used in the studies conducted by Warren et al. (2020) in Australia where the authors used daily grids of merged radar data including MESH at a $1 \mathrm{~km}$ resolution from 2009 until 2017. A pronounced peak of hail appeared during (Southern Hemisphere) summertime in December on the coastal slopes of the Great Dividing Range. In Czechia, Skripniková and Řezáčová (2014) used the Waldvogel criterion on single-polarization radar data to retrieve hail signals for the period 2002 until 2011. The authors found that hail occurred mostly during May, June and July during the afternoon throughout the country. Despite the use of improved radar-based techniques, most of the studies cited above were restricted to smaller regions or a single country. While some authors have estimated hail frequency from other sources such as overshooting tops (an indicator of strong convective updrafts) in satellite imagery (Punge et al., 2014), model data (Mohr et al., 2015a, b; Rädler et al., 2018) or a combination thereof (Punge et al., 2017), radar proxies have a key benefit over overshooting tops as they represent a more direct measure of hail within a storm (presence of large reflectivities). Numerical models, such as weather forecast models or regional climate models (RCMs), on the other hand, are not able to reliably reproduce hail due to a high degree of uncertainty in the initial conditions, a lack of knowledge in cloud microphysics and the high computer costs when running a two- or three-moments microphysics scheme. The big advantage of satellite or model-based hail proxies is that they cover large areas more or less homogeneously, whereas radar-based climatologies are typically limited to a single country or region.

Our study is the first to combine radar observations from multiple countries. Indeed, the objective of our study is to analyze the spatiotemporal variability of hail signals over a 10 year period (2005 to 2014) covering the four European countries of France, Germany, Belgium and Luxembourg. Hail signals were estimated from $2 \mathrm{D}$ radar reflectivity available for each country, which permits a homogeneous hail analysis. The results help us identify regions frequently affected by hail and allow us to relate hail frequency to topographic features such as terrain height or the proximity to the sea. A thorough study of hail events gives further insights into the relation between orography and deep moist convection. Improved understanding of these mechanisms and processes is crucial for improving the nowcasting and forecasting skill of hailstorms. Finally, as hail constitutes a considerable risk for the insurance industry, improved knowledge about hail frequency and hailstorm characteristics will help us better understand the related risks.

The paper is structured as follows: Sect. 2 gives an overview of the remote-sensing and reanalysis datasets used for this study. Section 3 describes the combination of radar data with lightning data and the application of the tracking algorithm. The remote-sensing output is then used to generate European composites at $5 \mathrm{~min}$ time steps. Section 4 assesses the hail variability between 2005 to 2014 in relation to the distance to the sea and the presence of orography near hailstorms. This section also presents results on seasonal and diurnal variations in hail frequency and provides some characteristics of the hail cells. Concluding remarks follow in Sect. 5. 

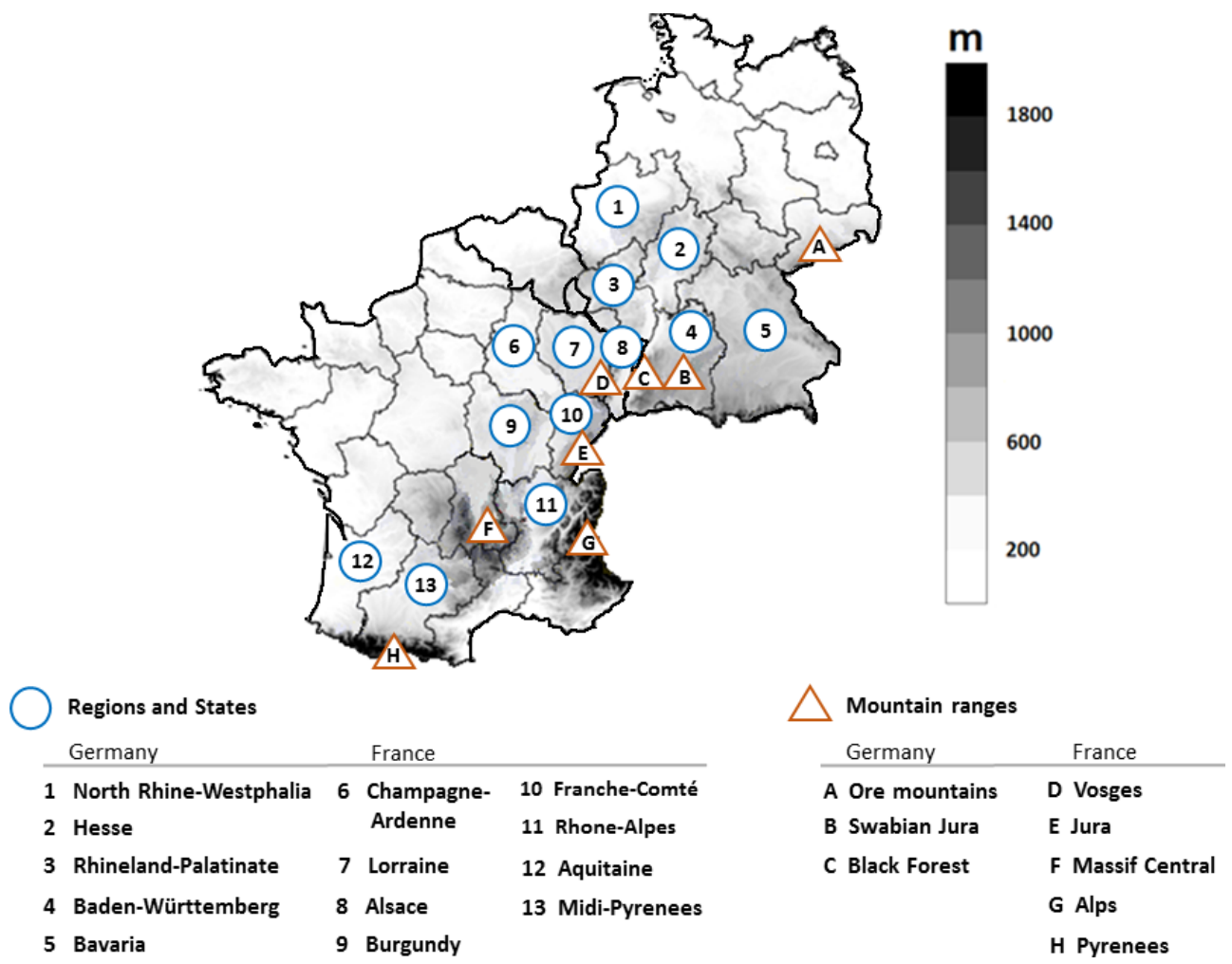

Figure 1. European regions and mountain ranges mentioned in this study.

\section{Datasets}

\subsection{Remote-sensing data}

In this paper, we present a hail climatology retrieved from radar reflectivity datasets available from the first phase of the project HAMLET (Hail Model for Europe by Tokio Millennium) that lasted from 2013 until mid-2017. 2D radar reflectivity for the summer half years (April to September) from 2005 to 2014 for Germany, France, Belgium and Luxembourg are considered (Fig. 1). The French national radar composites were available until 2014 only, due to the installation of five new X-band radars in the alpine region in 2014 (see Sect. 2.1.1), which required some additional time to calibrate each X-band radar and to implement their data into the national radar composite. The French national radar composites from 2015 onward, including the X-band radars in the alpine region installed in 2014 , were only available later. The radar products used in this study are composites of the Maximum Constant Altitude Plan Position Indicator (MaxCAPPI), where the composite is a merger of the data from all local radar stations in a single image at time steps of $5 \mathrm{~min}$. 2D radar data are used here because of the large domain and their long-term availability.

\subsubsection{French radar data}

The French radar network operated by Météo-France and the derived radar products evolved constantly through time, mainly via national projects. A brief overview of the French radar network is given here. In 2001, 19 radars constituted the French radar network. One year later, in 2002, five new radars were added to the network and some of the 19 radars were replaced by dual polarization radars (Tabary et al., 2006; Bousquet et al., 2008). In 2005, 24 radars were in operation including $19 \mathrm{C}$-band radars and five S-band radars (both with a radius of up to $120 \mathrm{~km}$ ). Two years later, in 2007, the radar stations of Toulouse in southwestern France and Trappes (near Paris) were renewed (Tabary, 2007), but this replacement did not affect the radar national composite. During the period from 2007 to 2011, the radars of Plabennec located in northwestern France, Abbeville in northern France, Nimes in southern France and Grèzes in the southern part of central France were replaced with dual polarization radars as well. In 2014, five X-band radars with an average coverage radius of $50 \mathrm{~km}$ were added to the French national radar composite in the alpine region (Beck and Bousquet, 2013; Champeaux et al., 2011). As the data from the $\mathrm{X}$-band radars were only recently implemented into the French national composite (Yu et al., 2018), only S- and C-band radars were considered in this study. Note that the radar stations of Avesnois (located in northern France) and Réhicourt-la-petite in Lor- 


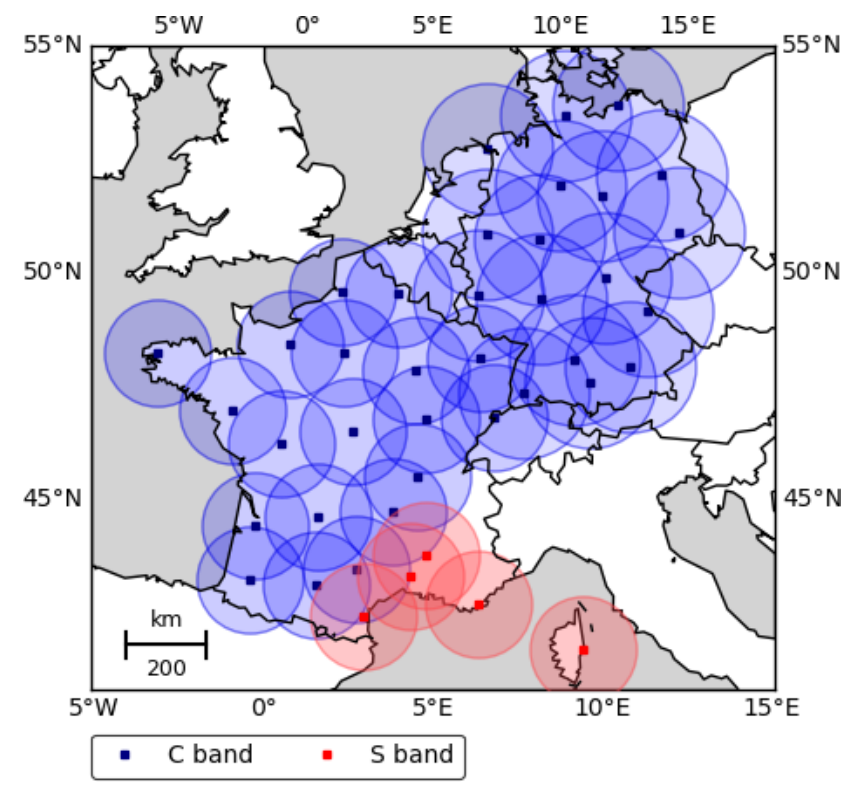

Figure 2. Locations (squares) and coverage of the radar stations (circles) in 2014 used in this study. See text for further explanations.

raine (labeled as 7 in Fig. 1) cover a large part of eastern France and permit the complete integration of Luxembourg, as well as a significant part of Belgium, into the French national composite.

Concerning the scanning strategy, four to six scans are performed every $15 \mathrm{~min}$ at elevation angles ranging from 0.4 up to $15^{\circ}$ (Figueras i Ventura and Tabary, 2013). Only lower elevation angles below $2.7^{\circ}$ are scanned every $5 \mathrm{~min}$. The spatial resolution of the composite is $1 \times 1 \mathrm{~km}^{2}$ with a size of $1536 \times 1536$ grid points for each image referenced to a plane Cartesian coordinate system (Tabary et al., 2006). Radar data from all stations are preprocessed via an algorithm (Tabary, 2007) named Castor2 (Figueras i Ventura et al., 2012), which corrects for several errors, such as antenna positioning errors, and quantifies horizontal reflectivity $Z_{\mathrm{h}}$ in polar coordinates (Tabary, 2007). During the preprocessing stage, each radar pixel receives a weighted quality index (QI) ranging from 0 to 1 (Tabary, 2007), updated throughout the whole preprocessing chain. The first preprocessing step is to eliminate ground clutter, i.e., fixed echoes at the surface, using Doppler velocity (Tabary et al., 2013). Then an orographic mask is applied at each elevation angle in order to assess the beam occultation rate. After that, an "anthropogenic" mask, including buildings, trees or other fixed objects in the vicinity of the radar is computed with the help of long-term accumulated radar products. These masks allow one to remove radar pixels with artificially high reflectivity at each elevation angle. The underestimation of reflectivity above the $0{ }^{\circ} \mathrm{C}$ isotherm is taken into account (Tabary et al., 2013) using vertical reflectivity profiles. Attenuation by oxygen is corrected depending on the wavelength, the elevation and the distance to the radar (Doviak and Zrnić, 2006). For example, a correction of $1.79 \mathrm{dBZ}$ at $100 \mathrm{~km}$ away from the radar site is applied to C-band radars for an elevation angle of $0.4^{\circ}$ (Tabary et al., 2013). One of the last preprocessing steps is the correction of the bright band with the help of vertical reflectivity profiles. After performing all the steps described above, individual plan position indicators (PPIs) are combined to 2D composites produced every $5 \mathrm{~min}$ available for each radar station. All individual radar products are then combined into a national mosaic (Augros et al., 2013). For areas with overlapping radar coverage, weighted reflectivity data are computed depending on the distance to the nearest radar (Tabary et al., 2013). At the borders of France, radar data from other national weather services are integrated into the French national mosaic. Reflectivity values from the French radar mosaic used in this study were coded in a table and stored in GeoTIFF format, i.e., georeferenced TIFF images. The resolution is $2 \times 2 \mathrm{~km}^{2}$ from 2004 until mid-June 2009, and a finer resolution of $1 \times 1 \mathrm{~km}^{2}$ is available from mid-June 2009 to 2014. For data homogenization, each of the $2 \times 2 \mathrm{~km}^{2} \mathrm{com}-$ posites was interpolated linearly from 2004 to June 2009 to the finer grid of $1 \times 1 \mathrm{~km}^{2}$.

\subsubsection{German radar data}

The German radar composites for the period from 2005 to 2014 are provided by the German Weather Service (DWD), which operated a network of $17 \mathrm{C}$-band radar systems in 2014. During the investigation period, a new radar in Memmingen, southern Germany, was added to the network in 2012 (Puskeiler, 2013). As the horizontal range detection for each radar is $180 \mathrm{~km}$ and a maximum distance of $200 \mathrm{~km}$ separates the radar stations, an extensive overlap of the detection areas permits almost a complete coverage of the German territory. Only some peripheral regions are not well covered by the composite, for example, in the far north near the Danish border and in southeastern Bavaria (Fig. 2). In the complex terrain of southern Germany, weather radars are preferably located on hills and mountains to minimize beam shielding by orography. Concerning the scanning strategy, the lowest elevation angles between 0.5 and $1.8^{\circ}$ (Bartels et al., 2004) at that time were scanned every $5 \mathrm{~min}$, whereas a complete volume scan took $15 \mathrm{~min}$. The maximum reflectivity values of the lowest elevations are used for the national 2D reflectivity composite. The preprocessing steps are similar to those of Météo-France and include, among others, an elimination of clutter pixels using a clutter filter and orographic shading correction using an elevation model. After preprocessing, the local radar data are merged into the German national composite. For areas with overlapping radar coverage, the maximum reflectivity value from all radar scans is used in the composites, while for the neighboring regions of foreign countries, a weighted adjustment is performed between radar products from other national weather services and the German rain-gauge dataset (Kreklow et al., 2020). The quality 
of German radar data has improved over the last decade with continuous algorithm corrections and adjustments (Kreklow et al., 2020) used for RADOLAN (Radar-Online-Aneichung, which means Radar Online Adjustment) and can be assessed by a quality flag provided for each pixel on the reflectivity product. The spatiotemporal resolution as well as the time period available for the German radar data are the same as for the French data, namely $1 \times 1 \mathrm{~km}^{2}$ with a 5 min time step for the composite and available from 2005 until 2014, so both data sets can be merged. The encryption of each scan of the DWD network entails near-ground reflectivity values (named RX products) in so-called RVP6 units. The advantages of these data are the high temporal and spatial resolution, which enables us to properly identify footprints of SCSs. RX data are projected on a Cartesian grid so that each grid box is equidistant at $1.0 \mathrm{~km}$. In the end, the German radar composite has a size of $900 \times 900 \mathrm{~km}^{2}$ covering the whole of Germany.

\subsubsection{Uniform pan-European grid}

It is important to note some limitations in both the German and French national composites. Long-term QPE (Quantitative Precipitation Estimation) maps for the French national composite reveal some regions with low data accuracy. This is mainly the case for the central and eastern part of the Pyrenees mountains and the entire alpine region (Tabary et al., 2013). In the other parts of France, the QI is mostly higher than $90 \%$ with especially high QIs close to the radar site (Tabary et al., 2013). Radar data failure, for example during radar calibration or radar replacement, was estimated by Puskeiler et al. (2016) to be approximately $4.5 \% \pm 3.9 \%$ on average (mean \pm standard deviation for the German national composite). Furthermore, the combination of the German and French national composites, each calibrated and preprocessed in different ways, may lead to inhomogeneities in relative hail frequency in some regions. Based on manual investigation of several cases with severe hailstorms in the border region between Germany and France, it was found that the signal of the French mosaic is between 0.5 and $1 \mathrm{dBZ}$ lower compared to that obtained from the DWD composite (Schmidberger, personal communication, 2020). This uncertainty is acceptable when projecting the two national composites onto a uniform pan-European grid. Radar reflectivity data and thus radar-derived hail signals were projected on the same uniform European grid (not shown) with a resolution identical to that of the national radar network $\left(1 \times 1 \mathrm{~km}^{2}\right)$. We used the geographic coordinate system WGS84 for the panEuropean grid and a Lambert conformal conic projection, as recommended by Gregg and Tannehill (1937) and Varga (1990). In the center, at about $47^{\circ} \mathrm{N}$ and $6^{\circ} \mathrm{E}$, the meridional grid spacing is equal to the zonal direction to minimize the grid distortion.

\subsubsection{Lightning data}

To remove artificial clutter still present in the data, we additionally implemented a filter based on lightning data, which was already used by Puskeiler et al. (2016). Here we used only cloud-to-ground (CG) lightning (strokes) from the lowfrequency lightning detection system BLIDS (BLitz InformationsDienst Siemens), which is part of the EUCLID (EUropean Cooperation for LIghtning Detection) network. The detection efficiency of the system is $96 \%$ for strokes with a peak current of at least $2 \mathrm{kA}$ (Schulz et al., 2016). Because the sensors and the algorithm implemented until 2015 had a significantly lower detection efficiency of intracloud and cloud-to-cloud lightning according to Pohjola and Mäkelä (2013), these types of lightning were not considered.

\subsubsection{ERA5 reanalysis}

To assess the mean wind flow during hail days, we used the ERA5 global reanalysis (Hersbach et al., 2020). ERA5 is a new global atmospheric reanalysis recently released by the ECMWF and aims to replace ERA-Interim reanalysis (Dee et al., 2011) whose data extend from 1979 to 2019. For the moment, ERA5 is available from 1979 onwards and will be soon extended to 1950. The ERA5 4D-Var analysis dataset is assimilated by the Integrated Forecasting System (IFS) and is available on a horizontal resolution of $0.25^{\circ}$ on 137 vertical levels every hour.

\section{Methods}

\subsection{Correction of erroneous signals}

Concerning the homogenization of the French and German national composites, several corrections had already been performed by both national meteorological services. Radar reflectivity data still contain noise and systematic errors that have to be eliminated using various approaches. Errors mostly concern individual radar pixels with significantly higher reflectivity values (e.g., more than $70 \mathrm{dBZ}$ ) compared to the surroundings. To avoid this problem, reflectivities below $35 \mathrm{dBZ}$ or above $70 \mathrm{dBZ}$ were set as missing values. Following Puskeiler et al. (2016), an additional verification and correction filter was applied for reflectivity values of $Z>45 \mathrm{dBZ}$ with a difference of $\Delta Z>5 \mathrm{dBZ}$ to the adjacent pixels. The affected pixel is set to the mean value of its eight surrounding pixels and this filter was applied to all consecutive radar scans:

$$
Z(x, y)=\frac{1}{8}\left(\sum_{i=-1}^{1} \sum_{j=-1}^{1} Z(x+i, y+j)-Z(x, y)\right) .
$$

In addition, if a reflectivity value at a given grid point is at least twice as high compared to the eight neighboring val- 
Table 1. Thresholds required in radar composites to identify potential convective cells with the CCTA2D algorithm.

\begin{tabular}{lrl}
\hline Description & Value & Units \\
\hline Minimum reflectivity of an ROIP & 35 & $\mathrm{dBZ}$ \\
Minimum reflectivity of an RC & 55 & $\mathrm{dBZ}$ \\
Reflectivity to subtract from ROIP maximum & 10 & $\mathrm{~dB}$ \\
Minimum RC area & 5 & $\mathrm{~km}^{2}$ \\
Minimum number of pixels inside an RC & 3 & $\mathrm{~km}^{2}$ \\
\hline
\end{tabular}

ues and was not present in the scan before or afterward, the reflectivity value is considered an artifact and set to zero.

\subsection{Lightning filter}

Although the radar tracking routine (see next paragraph) includes a clutter filter, several erroneous signals are still present in the radar data. For example, isolated nonmeteorological targets such as electronic signals or reflectivities from wind turbines can emerge in radar scans (Steiner and Smith, 2002). Since hail occurs only in association with thunderstorms (Baughman and Fuquay, 1970; Changnon, 1999; Wapler, 2017), lightning is expected near high reflectivity cores. In addition to the gradient filter described above, we used lightning detections to further remove artificial clutter. If high reflectivity values $(Z \geq 55 \mathrm{dBZ})$ occur during a $24 \mathrm{~h}$ period without lightning, the values at the affected grid points are set to zero. A maximum distance of $10 \mathrm{~km}$ was chosen between a lightning discharge location and the pixels with high reflectivity. Distances of 5, 15 and $20 \mathrm{~km}$ were also tested. A distance of $5 \mathrm{~km}$ led to the disruption of several hail tracks due to gaps in reflectivity values; the other two thresholds affected the results only marginally. An example of the lightning filter application during a hailstorm can be found in Fluck (2018) for the 27 July 2013 at 15:30 UTC.

\subsection{The convective cell tracking algorithm CCTA2D}

The object-based Convective Cell Tracking Algorithm (CCTA2D) permits the reconstruction of tracks of individual convective cells using 2D radar data. The algorithm is based on the tracking algorithm TRACE3D (Handwerker, 2002), originally developed and optimized for 3D radar reflectivity from a single radar in spherical coordinates. TRACE3D was further extended to radar reflectivity data in Cartesian coordinates such as those provided by the DWD radar network (Puskeiler et al., 2016). A second version was adapted to $2 \mathrm{D}$ terrain following near-ground reflectivity (CAPPI) using both the RX product from the DWD and French mosaic including France, Belgium and Luxembourg (Fluck, 2018).

The first step of CCTA2D is to identify regions of intense precipitation (ROIP) delimited by $Z \geq 35 \mathrm{dBZ}$ and to determine the corresponding maximum reflectivity values $\left(Z_{\max }\right)$. In order to distinguish individual reflectivity cores (RCs) within each ROIP, a value of $\Delta Z=10 \mathrm{dBZ}$ is subtracted from $Z_{\max }$ to set the minimum threshold necessary to delimit an single $\mathrm{RC}\left(Z_{\mathrm{rc}}\right)$. Thus, the value of $Z_{\mathrm{rc}}$ remains the same for all identified RCs inside a ROIP. If $Z_{\mathrm{rc}}$ is less than $55 \mathrm{dBZ}$, the $\mathrm{RC}$ is rejected and not tracked by CCTA2D. Two additional conditions are required for an $\mathrm{RC}$ to be classified as a potential convective cell and to be tracked by CCTA2D: a minimal area of $5 \mathrm{~km}^{2}$ is needed to define an RC with at least $3 \mathrm{px}$ (pixels) $\left(\mathrm{km}^{2}\right)$ of $Z \geq 55 \mathrm{dBZ}$. The thresholds detailed above to identify potential convective cells in CCTA2D are summarized in Table 1 . The $55 \mathrm{dBZ}$ threshold is referred to as the hail criterion according to Mason (1971) and was successfully used in several studies (e.g., Hohl, 2001; Hohl et al., 2002; Kunz and Kugel, 2015). Schuster et al. (2005), for example, found $55 \mathrm{dBZ}$ to be a good indicator for damaging hail on the ground in eastern Australia. Puskeiler et al. (2016) estimated a slightly higher threshold of $56 \mathrm{dBZ}$ to best differentiate between days with and without insured damage to buildings but confirmed that $55 \mathrm{dBZ}$ best estimates insured damage to crops. Categorical verification using insurance loss data over a 7 year period in southwest Germany for this threshold yields a Heidke skill score (HSS) of 0.6, a quite high value confirming the detection skill (it should be noted that this value increases to HSS $=0.71$ when using an adjusted version of the Waldvogel et al. (1979) criterion requiring 3D radar data). In the same study, Puskeiler et al. (2016) found that the probability of detection (POD) reached 0.65 and the false alarm ratio (FAR) was 0.4 , indicating that $35 \%$ of the observed hail events are missing while $40 \%$ of those predicted events are false alarms.

The second step of CCTA2D is the temporal and spatial tracking of all detected convective cells. The algorithm associates RCs between consecutive radar composites according to the estimated propagation velocity and the position of the $\mathrm{RC}$. The prerequisite of the tracking is that an RC's intensity and size, from one time step to the next, must exist within a certain search radius for accurate RC assignment and tracking. The search radius is given by the estimated distance of an initial RC displaced during a time step of 5 min multiplied by a velocity factor of 0.6 .

Special attention is given to cell splitting and merging. Cell splitting is a prominent feature of supercells associated with vertical pressure disturbances. In the Northern Hemisphere, where the hodograph is usually right-curved, right-moving storms tend to be favored compared to left-moving storms. Cell splitting may also occur due to changes in storm intensity that cause a single RC to break up (or vice versa in the case of cell merging). In order to track both cells after they have split, a splitting (merging) option in the tracking algorithm is necessary. Furthermore, without splitting or merging options, the physical characteristics of SCS tracks such as their length or their angle of orientation could be incorrectly computed by CCTA2D. To detect cell splitting, the initial cell (e.g., the "parent" cell) is first spatially displaced to the position of the following cell (e.g., the successor, or "child" cell), 
and their respective areas are compared (Handwerker, 2002). A split is defined when a cell at time $t$ can be associated with two cells at time $t+\delta t$. In this case the largest child cell inherits the history of the parent cell. Similarly, a merger is defined when two cells at time $t$ are associated with a single cell at time $t+\delta t$. In this case, the largest parent cell assigns a history to the child cell. The maximum distance between two $\mathrm{RC}$ centers that could merge is set to $10 \mathrm{~km}$. Initial and successor areas are then compared and the successor is placed at the weighted center of all initially detected cores. Merging occurs when the successor area is larger than the initial RC. To avoid reflectivity core crossings or overlapping, each RC is enumerated and recorded separately.

After the construction of entire cell tracks, the composite of maximum reflectivity on a given day does not provide a smooth result but a rather scattered product. This effect is most pronounced when the cells propagate further than their horizontal extent during a measuring interval. The faster the storms move, the more scattered is the maximum reflectivity projected on a $2 \mathrm{D}$ plane. This can substantially reduce reflectivity values between two scans even though a high-intensity storm crossed the area. A gap of reflectivity values can also appear on radar scans in regions with overlapping radar data, especially on neighboring countries such as in the Rhine valley. To consider this effect, an advection correction was performed following Puskeiler et al. (2016). A translation of the reflectivity cores is computed from one time step to the next considering the horizontal wind field estimated by CCTA2D along a track. The field of motion vectors are computed and projected on the German and French grid. Each point along a track includes a velocity shift vector in north-to-south $\boldsymbol{d} v$ and west-to-east $\boldsymbol{d} \boldsymbol{u}$ directions. The so-called shift vector $\boldsymbol{U}$ is denoted as

$\overrightarrow{\boldsymbol{U}}(x, y)=\left(\begin{array}{l}\boldsymbol{d} \boldsymbol{u}(x, y) \\ \boldsymbol{d} \boldsymbol{v}(x, y)\end{array}\right)$.

A method is applied to obtain smoothed reflectivity values along the tracks detected by the algorithm CCTA2D. First, a cluster or "cell" of reflectivity values is detected along the track at a time $t$. This cell includes the maximum reflectivity value at time $t$ as well as its $40 \mathrm{~km}$ by $40 \mathrm{~km}$ surroundings reflectivity values. After that, the cell is displaced along the track with a radius of $3 \mathrm{~km}$ (Puskeiler, 2013). Then, the first cell of reflectivity values is shifted forward in time and the second cell of reflectivity values is shifted backward in time. After that, reflectivity values inside both cells are averaged. This procedure is done for multiple intermediate time steps in order to create a smooth track.

In our analysis, long-living SCS tracks were compared with hail reports archived by the European Severe Weather Database (ESWD) operated by the European Severe Storms Laboratory (Dotzek et al., 2009) along the reconstructed storm tracks to assess the reliability of CCTA2D. In fact, in the recent paper by Kunz et al. (2020), the authors separate all SCS events used in this study from the hailstorm events by assessing the presence of hail using ESWD reports in the vicinity of SCS tracks. Out of 26012 SCS events in total, only 985 events could be confirmed by hail reports. The main reason for this significant reduction of confirmed hail events is that ESWD reports are by far not complete. Whereas most of the reports are available for Germany, there are far fewer hail reports in France, Belgium and Luxembourg.

\section{Results}

\subsection{Spatial distribution of hail}

Figure 3 presents the hail probability map for the radar domain (cf. Fig. 2) in terms of annual average hail days per year during the period from 2005 to 2014 with a resolution of $1 \times 1 \mathrm{~km}^{2}$ based on $2 \mathrm{D}$ radar reflectivity. A day is considered a hail day when the threshold of $55 \mathrm{dBZ}$ is exceeded in the daily maximum reflectivity composite after (i) data correction, (ii) filtering with lightning data and (iii) tracking with the object-oriented algorithm CCTA2D as described in the previous section. If the hail criterion of $Z \geq 55 \mathrm{dBZ}$ is fulfilled on a specific day at a single grid point, this grid point is set to 1 , otherwise it is counted as zero. The total of all days with hail over the entire 10 year period divided by the number of years yields the radar-based "hail climatology". In accordance with other hail frequency analyses (e.g., Puskeiler, 2013; Nisi et al., 2016, 2018; Junghänel et al., 2016), the term climatology is used here even though our investigation refers to a period far below a climatological time scale of $\geq 30$ years. Note that this climatology represents the spatial distribution of convective cells with high reflectivity but not directly of hail as the $55 \mathrm{dBZ}$ threshold does not guarantee hail on the ground. Similarly, the absence of high reflectivity does not ensure that hail did not occur (see Sect. 3.3). The term hail days used in the following parts of this study refers to the exceedance of reflectivity but not to confirmed hail observations.

As can be seen in Fig. 3, the spatial variability of hail days per year is very large, but some patterns with distinct minima or maxima can be identified. The lowest number of hail days per year is around the both the Atlantic and the Mediterranean, with low frequency over northwestern France, Belgium and northern Germany. Conversely, the highest number of hail days per year is located towards the east of France, with maxima present in contiguous area such as in central France (area MAS) or in southwestern Germany. Besides the recognizable structures of maxima and minima, some very patchy patterns appear, for example, in area ECG or LUX. As a result, an increasing gradient in the number of hail days per year can be recognized from northwestern France towards central France; a predominant gradient pointing from northern towards southern Germany can also be mentioned.

A detailed investigation of the hail hotspots is presented here. Figure 4 represents the location of the mean hail days 


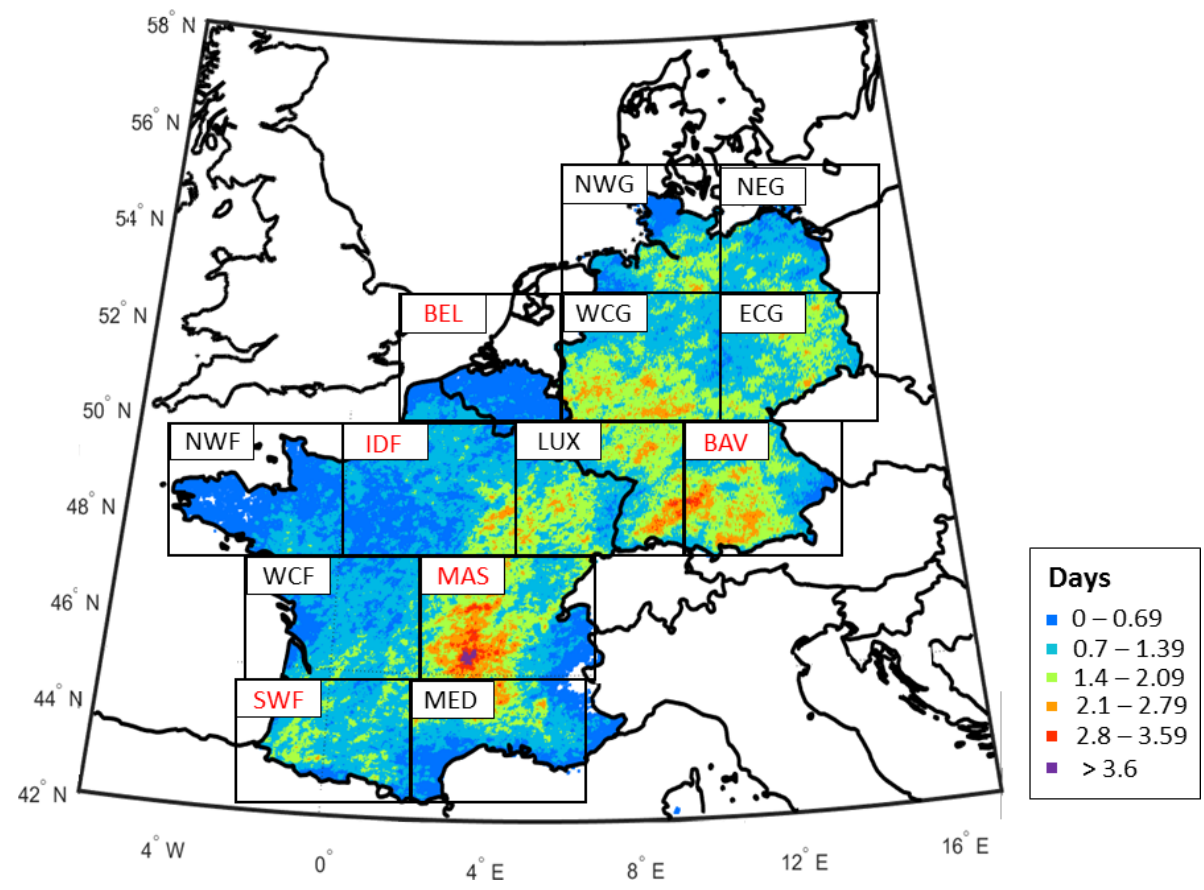

Figure 3. Annual radar-derived hail frequencies for $1 \times 1 \mathrm{~km}^{2}$ grid points in France, Germany, Belgium and Luxembourg between 2005 and 2014. Squares represent boundaries of subdomains further investigated in this study (see Sect. 4.3 for further details). The subdomains were named as follow: NWG (northwest Germany), NEG (northeast Germany), BEL (Belgium), WCG (west central Germany), ECG (east central Germany), NWF (northwest France), IDF (Île-de-France), LUX (Luxembourg), BAV (Bavaria), WCF (west central France), MAS (Massif Central), SWF (southwest France), MED (Mediterranean). Special emphasis is given for subdomains written in red.

per year in the Massif Central region overlaid with the $10 \mathrm{~m}$ mean wind during hail days from 2005 to 2014 on the highresolution global relief ETOPO1 having a 1 arc minute resolution (Amante and Eakins, 2009). The $10 \mathrm{~m}$ mean wind was computed using the hourly and $0.25^{\circ}$ horizontal resolution ERA5 global analysis (Hersbach et al., 2020).

The area with the highest average number of hail days per year during the 10 year investigation period is situated on the leeward side of the highest mountains of the Massif Central, averaging up to 4.6 hail days per year. This maximum extends over the central part over a few kilometers of the Massif Central (Livradois region) composed of a plain and middlerange mountains measuring up to $1300 \mathrm{~m}$ high (Livradois mountains). During days with hail, a strong flow comes from the Mediterranean Sea with a southerly direction, thus impinging the southern and southeastern mountains of the Massif Central at a sharp angle. Another general westerly flow reaches the western part of the Massif Central. Interestingly, it seems that not only the location of the Massif Central is responsible for the increased number of hail days downstream, but also the flow convergence where the westerly flow meets with the flow coming from the Mediterranean. One may speculate that even without the Massif Central, hail days might be increased in that area of low-level flow convergence. The large valleys on the western side of the Massif Central, oriented from southwest to northeast, facilitate

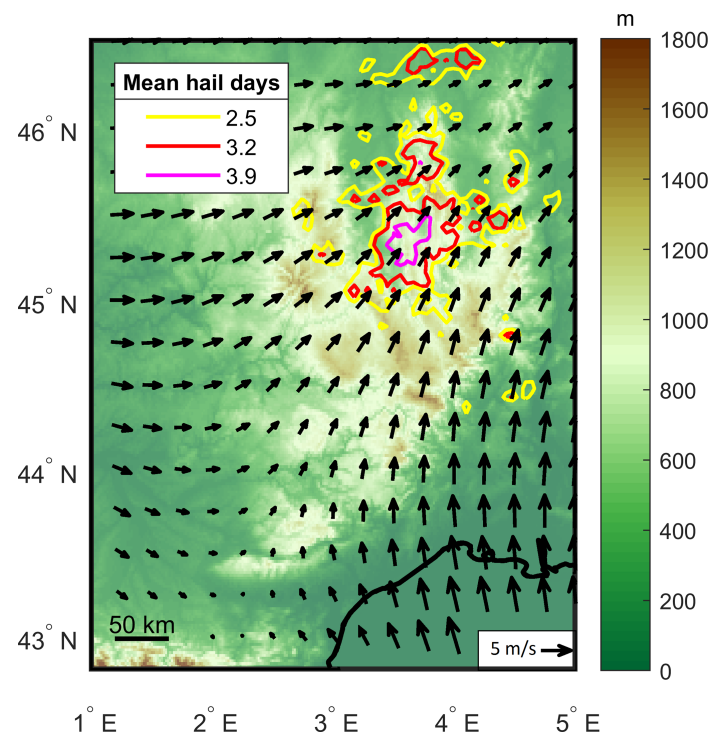

Figure 4. Contours of the average number of hail days per year from 2005 to 2014 overlaid with the orography and the $10 \mathrm{~m}$ mean wind flow during hail days. 
the passage of the flow coming from the southwest into the Livradois region. This region, with an average number of 3.2 hail days per year, is located in an area where the wind vectors converge both in the direction and velocity. In order to better understand the flow characteristics over the Massif Central shown in Fig. 4, we calculated the Froude number on radar-derived hail days from ERA5 (Queney, 1948; Smith, 1979) for a region covering the Massif Central entirely and ranging from 44.0 to $46.5^{\circ} \mathrm{N}$ and from 2.0 to $4.7^{\circ} \mathrm{E}$. The Froude number is calculated as follows:

$F r=\frac{U}{N H}$,

where $U$ represents the wind speed perpendicular to the mountain and was computed by applying a density-weighted integration over the lowest $2000 \mathrm{~m}$. $H$ is a characteristic mountain height set to $1300 \mathrm{~m}$ for the Massif Central region and $N$ is the Brunt-Väisälä frequency. The Brunt-Väisälä frequency, $N$, is defined as

$N=\sqrt{\frac{g}{\theta_{\mathrm{v}}} \frac{\partial \theta_{\mathrm{v}}}{\partial z}}$,

where $g$ is the gravitational acceleration equal to $9.8 \mathrm{~m} \mathrm{~s}^{-2}$, $\theta_{\mathrm{v}}$ is the virtual potential temperature and $\frac{\partial \theta_{\mathrm{v}}}{\partial z}$ represents the vertical gradient of the virtual potential temperature. In our analysis, we considered the root mean square of the BruntVäisälä frequency, $N$, in order to exclude imaginary values.

The mean Froude number on hail days over the Massif Central from 2005 to 2014 is $F r=0.39 \pm 0.3$. According to Smith (1979) and Smolarkiewicz and Rotunno (1989), a Froude number below 1 suggests a flow that goes around the mountain rather than directly over it. Thus, it can be assumed that the flow around the Massif Central is deviated by the mountain peaks leading to convergence downstream at low levels on the leeward side of the Massif Central where the hail hotspot is located. This deflection of the flow is unlikely to show up in Fig. 4 due to the fairly coarse resolution of the ERA5 reanalysis.

Several authors have found an increased hail frequency downstream rather than upstream or directly above the mountains. This is, for example, the case in the Pyrenean region (Vinet, 2001; Berthet et al., 2011; Hermida et al., 2013; Merino et al., 2013) near the Black Forest in Germany (Kunz and Puskeiler, 2010; Puskeiler et al., 2016) and in the vicinity of the Alps (Eccel et al., 2012; Nisi et al., 2018). By referring to the studies by Mass (1981) about leeward side convergence near the Olympic mountains in Washington State and by Barthlott et al. (2016) on convection initiation near the Corsica mountains during HyMeX (Hydrological cycle in the Mediterranean eXperiment), Kirshbaum et al. (2018) found that leeward side convergence produces the ascent required for convective initiation on the leeward side of mountains. Low-level flow convergence could explain the high frequency of hail on the leeward side of the Massif Central; however, this is still a hypothesis that requires additional observations and numerical simulations in this region to assess convection initiation.

The northeastern part of France, including the regions of Burgundy (region 9 in Fig. 1), Champagne-Ardenne (region 6), Alsace (region 8), Lorraine (region 7) and Franche-Comté (region 10) are affected with a maximum of 3.1 hail days per year in the central part of Burgundy and more precisely on the eastern side of mountains ranging from approximately 300 to $900 \mathrm{~m}$. In Champagne-Ardenne the number of hail days per year reaches up to $2.9 \mathrm{~d}$ over the mainly rolling terrain. In Lorraine, where the terrain is almost flat and the climate is more continental, an average of 2.7 hail days per year were counted in its central part. A local and lower maximum of 2.4 hail days per year can be recognized in South Alsace, representing an area with complex terrain with mountains up to $1424 \mathrm{~m}$ a.g.l.

Another hail hotspot in the northeastern part of France is found along the northern ridge of the Jura Mountains (labeled E in Fig. 1) in Franche-Comté with 2.5 hail days per year. Note that the Jura mountains represent a natural obstacle frequently triggering thunderstorms (Piper and Kunz, 2017) and hailstorms by orographical lifting (e.g., Langhans et al., 2013; Schemm et al., 2016; Nisi et al., 2018).

The Rhône-Alpes (region 11 in Fig. 1) is a region likewise frequently affected by hail. This region contains the large Rhône valley and is bordered by the Massif Central in the west and by the Alps to the east. The southwestern part as well as the southeastern edge of the region show a local hail maximum with up to 3.1 hail days per year. The existence of these two hotspots may be explained by their proximity to the Mediterranean as, during southerly flows, warm and moist air is advected preferably through the Rhône valley. The warm and moist air can then be lifted, for example, near a front system crossing the country from northwest to southeast, leading to forced convection. This effect was confirmed by Schemm et al. (2016), who analyzed the relation between radar-based hailstreaks over Switzerland and adjacent regions and cold fronts identified in high-resolution model data (COSMO-2; Steppeler et al., 2003; Jenkner et al., 2010) during a 12 year period (2002 to 2013). The authors found that around $45 \%$ of the detected hail cell initiations located on the windward side of the pre-Alps (in the Rhône valley) are associated with cold fronts coming from the west during the summer months (May to September).

Southwestern France, including both the Aquitaine and Midi-Pyrenees regions (regions 12 and 13 in Fig. 1), is also frequently affected by hail with up to 2.6 hail days per year in the southwest range of the Massif Central. The Aquitaine and Midi-Pyrenees regions are the two regions well known in the literature for their high hail probability (Vinet, 2001; Punge et al., 2014). Hermida et al. (2015) used data from the ANELFA (Association Nationale d'Etude et de Lutte contre les Fléaux Atmosphériques) hailpad network and found that the Gers department, located on the west side of the 
Midi-Pyrenees region, is the area the most affected by hail in southwestern France. The western and northern sides of the Pyrenees are also frequently affected by hail with up to 2.5 hail days per year. According to Berthet et al. (2011), hail in that region frequently occurs when a low-pressure system is located over the western part of Spain leading to southwesterly flow over France associated with the advection of warm and moist air over the Pyrenean mountain range.

In Germany, the main hail hotspot is located in the southwest in the federal state of Baden-Württemberg (region 4 in Fig. 1), specifically over the Swabian Jura (B in Fig. 1), south of the city of Stuttgart, with a maximum of 3.1 hail days per year. This hotspot has already been identified in previous studies by Puskeiler (2013) and Junghänel et al. (2016). Using Eq. (3), we found a Froude number of $F r=0.51 \pm 0.6$ for 207 hail days during the period 2005 to 2014 for a region covering 48 to $49.2^{\circ} \mathrm{N}$ and 7.8 to $10.5^{\circ} \mathrm{E}$, including the Swabian Jura as well as the Black Forest and considering a maximum elevation of $1400 \mathrm{~m}$ for the entire area. The Froude number found in our study in the southwestern part of Germany matches the results of Kunz and Puskeiler (2010) who estimated a Froude number for a region covering the Vosges mountains, the Rhine valley, the Black Forest and the Swabian Jura of $F r=0.32 \pm 0.15$ for 65 hail days (1997-2007) using radiosondes at 12:00 UTC. This low Froude number suggests a flow-around regime of the southern and northern mountains of the Black Forest causing a zone of horizontal flow convergence downstream. This convergence zone coincides with the area of the highest number of hail days (Kunz and Puskeiler, 2010; Koebele, 2014). Moreover, Kunz and Puskeiler (2010) hypothesized that the southwesterly flow meets the Swabian Jura at a very sharp angle, which reduces the Froude number considerably and aligns the wind parallel to the mountain chain. This flow modification is assumed to be responsible for the flow convergence at low levels as was also found in model simulations using COSMO-DE by Koebele (2014).

Another local maximum of up to 2.6 hail days per year is found north of the Alps, on the western part of the State of Bavaria (region 5 in Fig. 1). This result is in good agreement with the conclusion of Nisi et al. (2018) who found that this region can be affected by around 3 hail days per year (20022014).

In the northeast of Germany, a local maximum of up to 3.2 hail days per year is positioned over the Saxon Ore Mountains (labeled A in Fig. 1) south of the city of Dresden. Note, however, that this maximum is mainly caused by a high number of SCSs in the year of 2007 (Piper, 2017), which was characterized by frequent upper air troughs over western Europe and ridges over central Europe (Wernli et al., 2010), leading to high-pressure gradients on the eastern part of Germany in combination with a southeast-to-northeast flow regime from Czechia (note that the almost same situation occurred in 2019).
The northwestern part of Germany, including the states of Hesse (region 2 in Fig. 1) and Rhineland-Palatinate (region 3 in Fig. 1), and the southern part of North Rhine-Westphalia (region 1 in Fig. 1) are regions affected by approximately 1.4 hail days per year on average. The location of the hail patterns show an association with the local orography with a pronounced maximum in north Hesse that lies directly on the leeward side of the Westerwald low mountain range, which is characterized by rolling terrain.

\subsection{Annual variability}

The frequency of SCSs shows a very large annual and multiannual variability (e.g., Nisi et al., 2018). This variability is partly related to large-scale flow mechanisms such as the presence of specific Northern Hemisphere teleconnection patterns representing the low-frequency mode of the climate system (e.g., North Atlantic Oscillation (NAO) or East Atlantic (EA) pattern) or by variations in the sea surface temperature (Piper et al., 2019). Having reconstructed a very large event set of SCSs/hailstorms, as presented in the previous section, we are also interested in how the frequency of these events vary across the whole domain and regionally.

Averaged over the entire investigation area, the annual number of hail days is between 72 (2010) and 103 (2006) with a mean of 86 (Fig. 5). In 2006, large parts of Europe, including Germany, Belgium, Luxembourg and northwest France, experienced higher temperatures than on average, especially during the end of June and July (NOAA, 2007), when two (moderate) heat waves occurred (Fouillet et al., 2008). As a result, the sea surface temperature over the Mediterranean showed a positive anomaly (NOAA, 2007; Lenderink et al., 2009), leading to intense evaporation rates and, consequently, to an increase in the amount of water vapor in the atmosphere (Chaboureau et al., 1998). The spatial distribution of hail days in 2006 (Fig. 6) strongly resembles the climatology, with several maxima near hilly terrains and minima near the coastlines. Some hotspots can also be detected over the northwest part of France and in southwestern Germany.

Even though the year of 2010, showing the lowest number of hail days, was very warm on the global scale (NOAA, 2011), summer temperatures over large parts of Europe including Germany were below average. Furthermore, several persistent large-scale ridges occurred during the summer, which may have suppressed the formation of SCSs (DeutscheRück, 2013). No clear spatial pattern can be found in this year with only a few hailstorms in central France. Almost no hailstorms could be detected in an arc spanning from northwestern France to northern Germany. There are further regions where hail was less present compared to the mean of 2010, including all of Belgium, Luxembourg and the northwest of France, especially Normandy, Brittany and the coastlines. 


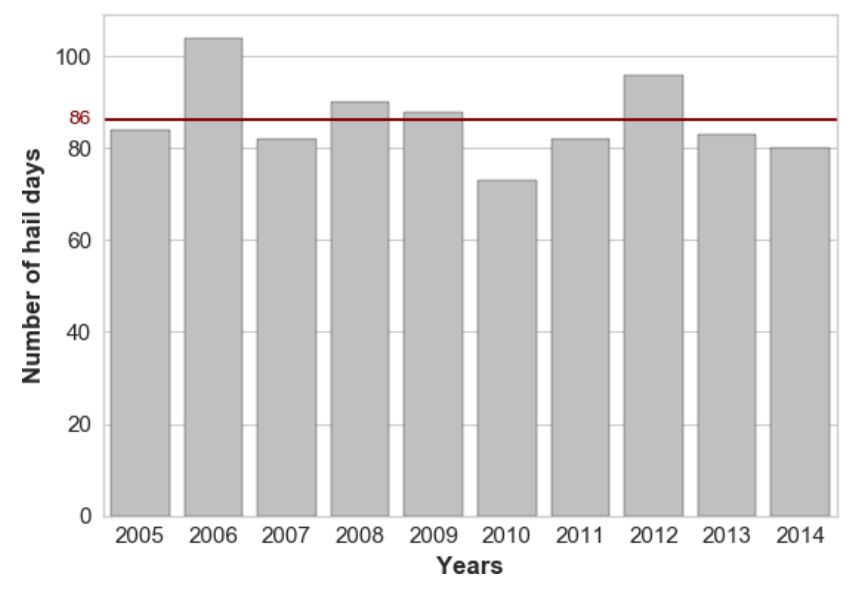

Figure 5. Yearly number of hail days per year from 2005 to 2014. The red line indicates the overall mean of hail days from 2005 to 2014.

\subsection{Seasonal and diurnal development of SCSs}

The large spatiotemporal variability of hail discussed in the previous sections leads us to the question of the seasonal and diurnal development of SCSs at the regional level. For this purpose, the entire study area is divided into 13 subdomains of similar size (around $75000 \mathrm{~km}^{2}$ ) framed in Fig. 3 . We selected five subdomains with different terrain and climatological characteristics for further discussion: Belgium (BEL), Ile-de-France (northern France; IDF), Bavaria (southeastern Germany, BAV), the Massif Central (central France; MAS) and southwest France (SWF). Subdomains BEL, SWF and IDF have a climate strongly influenced by maritime air masses. Among them, subdomains BEL and IDF represent flatlands, while subdomain SWF contains the high mountains of the Pyrenees. Subdomains BAV and MAS both have a rather continental climate but have a different orography. While mainly hilly terrain characterizes subdomain BAV, subdomain MAS comprises the higher mountains of the Massif Central.

To quantify the number of hail days in each subdomain, the average number of hail days for consecutive $10 \mathrm{~d}$ periods was calculated for the period 2005 to 2014 (Fig. 7). Despite the large variability seen in the seasonal cycles of the subdomains considered, some similarities can be recognized. All time series of the different subdomains feature a clear annual cycle with a minimum number of hail days in spring and autumn and a maximum number during the summer. This characteristic cycle with a strong increase in the hail day frequency during April/May, a significant decrease around September and a maximum during the summer months was found by several other authors such as Dessens (1986) and Vinet (2002) for France, Belgium and Luxembourg, Gudd (2003), Deepen (2006), Mohr and Kunz (2013) and Puskeiler et al. (2016) for Germany and Nisi et al. $(2014,2018)$ for Switzerland and northern Italy.
The mountainous subdomain MAS shows the largest average number of hail days and has the most pronounced annual cycle. Until the end of April, the average number of hail days for the $10 \mathrm{~d}$ running mean is below 10. During May and the beginning of June, the number increases substantially from $9 \mathrm{~d}$ around 5 May up to $17 \mathrm{~d}$ on 4 June. The more pronounced diurnal temperature cycle for continental regions, associated with a higher lapse rate in combination with orographic lifting, may explain this increase (Berthet et al., 2011). After 4 June, the average number of hail days increases steadily until reaching the overall maximum for the MAS region at the end of July with $23 \mathrm{~d}$.

Likewise, subdomain IDF shows a high hail frequency during the summer with up to $14 \mathrm{~d}$, mainly at the end of July. This subdomain is under the influence of the Atlantic Ocean (Cantat, 2004), leading to an increased frequency of troughs (Vinet, 2001, Berthet et al., 2013).

Within this subdomain, the number of hail days increases slightly until the peak with a first local maximum in the beginning of June (around 10 hail days) and a second local maximum at the beginning of July with around 12 hail days. Spring hailstorms may be associated with subtropical air masses coming from Spain, while summer storms preferably form ahead of cold fronts (Berthet et al., 2011). The number of hail days decreases sharply from the hail peak season toward the end of September.

Subdomain SWF has a very broad hail peak in the middle of June with 12 hail days centered around 14 June. Afterwards, the number slightly decreases and reaches 4 hail days at the end of September. This maximum found in June differs from the analysis of Dessens et al. (2015), who found that May is the most active month followed by July over the southwestern part of France and the Mediterranean area (situated along the Rhône valley). Also, Fraile et al. (2003) and Hermida et al. (2013) found that May is the month with the highest hail kinetic energy in southwestern France. Reasons for this discrepancy can be due to a longer period analyzed by Dessens et al. (2015), while Hermida et al. (2013) and Fraile et al. (2003) focused on a time range starting from the 1990s.

Subdomain BAV, located in southeast Germany, has the maximum number of hail days at the end of July, later in the year than the other subdomains. Kunz and Puskeiler (2010) and Puskeiler (2013) also found that July is the month with the highest number of hail days in central and southern Germany.

Subdomain BEL, covering the north of France as well as much of Belgium, peaks at the end of June. A 10 year radarbased climatology conducted for Belgium by Lukach and Delobbe (2013) also found that May and June are the most favorable months for hail.

The development of hailstorms shown in Fig. 8 represents the times where the CCTA2D detects the first radar reflectivity of $55 \mathrm{dBZ}$ or more. Since the local time (LT) varies through Europe by approximately $1 \mathrm{~h}$ from Brittany in France to Saxony in Germany, all times originally given in UTC are 


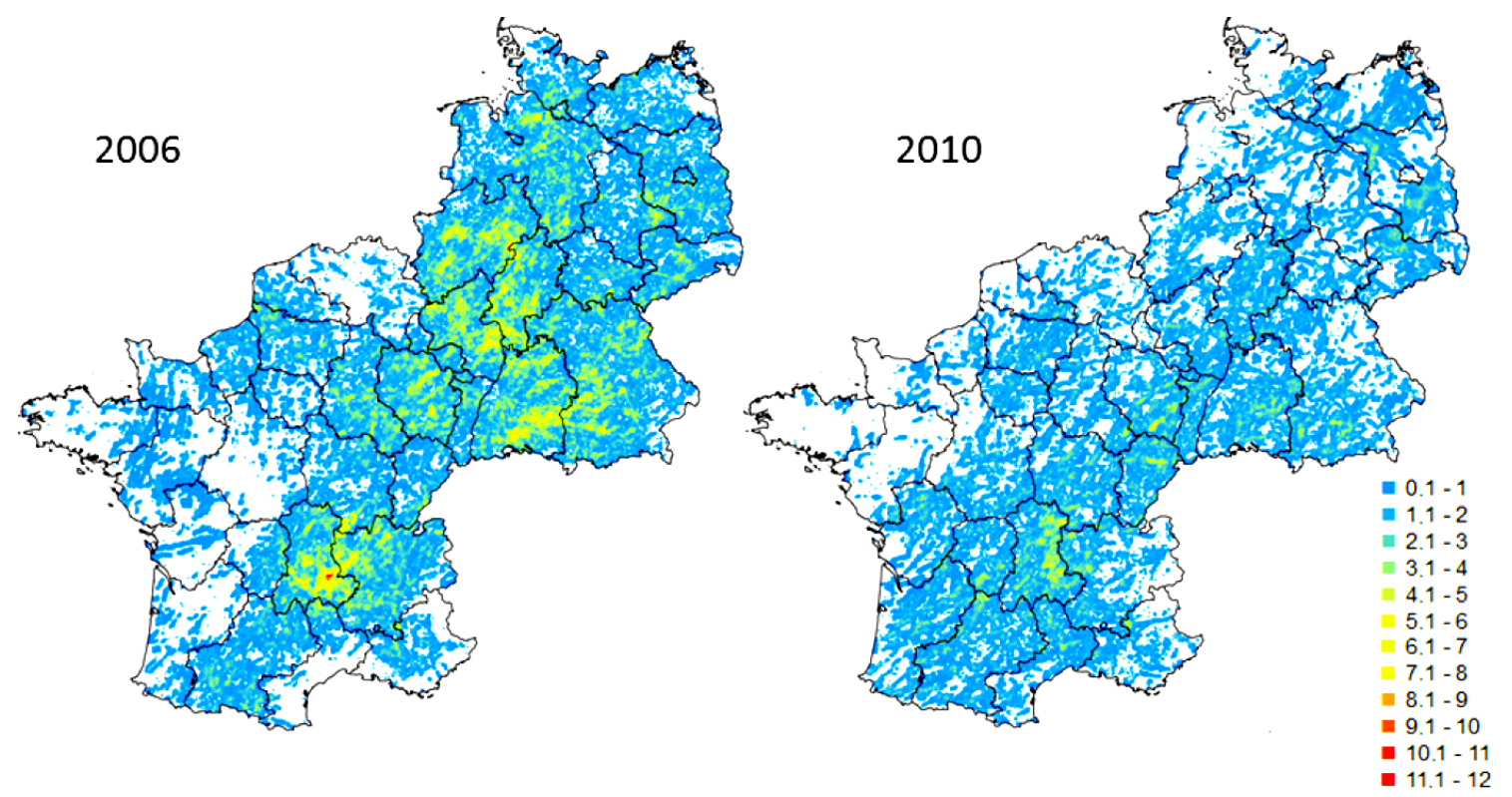

Figure 6. Number of radar-derived hail days shown for the years with the highest (2006, left) and lowest (2010, right) hail day frequency.

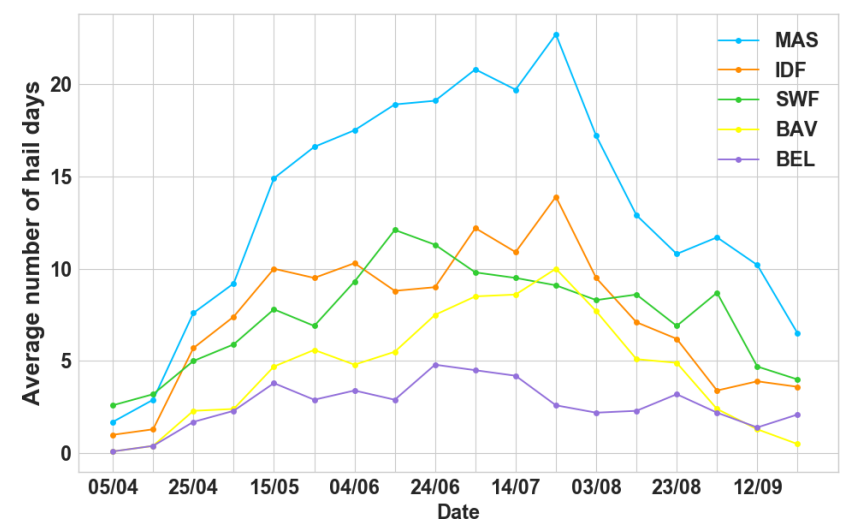

Figure 7. Time-series of the mean number of radar-derived hail days for consecutive $10 \mathrm{~d}$ periods for the subdomains BEL, IDF, BAV, MAS and SWF shown in Fig. 3.

converted to LT, representing 4 min per degree of longitude. In all subdomains, hail occurs most frequently in the afternoon between 13:00 and 18:00 LT, while between midnight and 10:00 LT the fewest events are detected (Fig. 8).

Some discrepancies appear in the daily cycle, mainly depending on the location and characteristics of the respective subdomain. For example, the frequency of hailstorms in BEL reveals a large increase during the afternoon (14:0015:00 LT) and a slow but gradual decrease toward the morning.

In contrast to the subdomains located in the northern part of Europe, domains MAS over the Massif Central and SWF slightly peak $1 \mathrm{~h}$ later at around 16:00 LT. The peak during the late afternoon for more continental regions is presumably

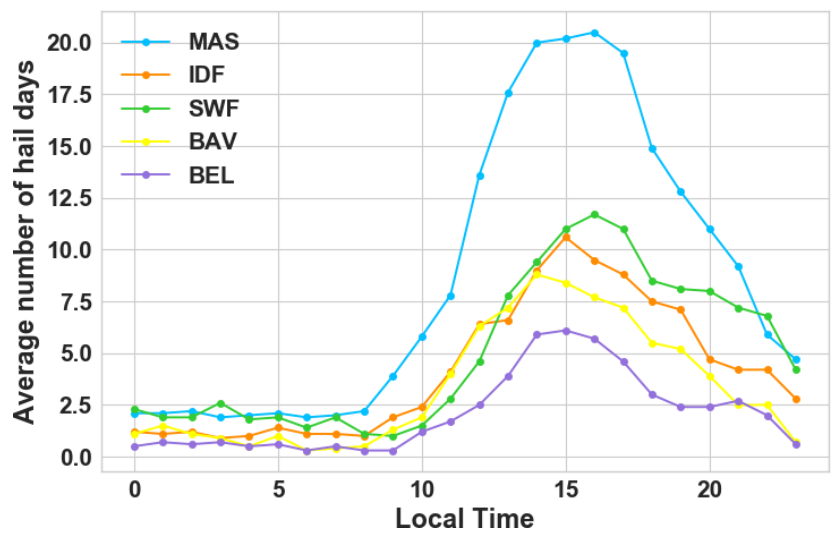

Figure 8. Hourly distribution of the mean number of radar-derived hail days for each subdomain.

due to local orographic effects, such as slope or valley winds (Nesbitt and Zipser, 2003).

For subdomain SWF, the average number of hail days remains high in the late evening (20:00 to 22:00 LT).

A plausible effect is that severe storms may develop from pre-existing scattered thunderstorms that form during the afternoon as was found by Nisi et al. $(2016,2018)$. This feature might be decisive for the hailstorm maximum in the evening in the canton of Ticino in southern Switzerland.

Some literature exists regarding the diurnal cycle of hail in Europe (Punge and Kunz, 2016). Bedka (2011), for example, recognized a diurnal cycle of overshooting tops that is related to the presence of orography and/or to the distance to the sea. Kaltenböck et al. (2009) found a peak in hail occurrence in the middle of the afternoon through Europe. Kunz 


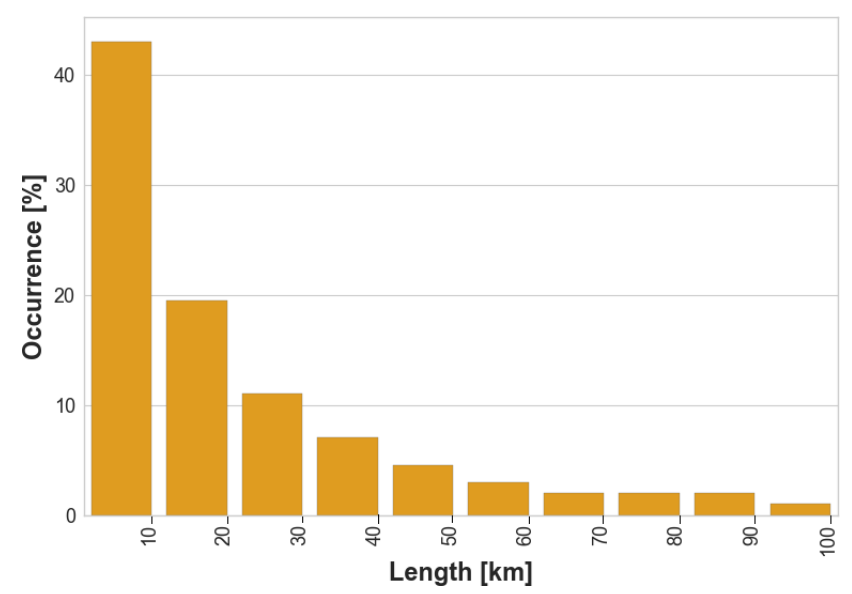

Figure 9. Histogram of all SCS mean lengths.

and Puskeiler (2010) identified for southwestern Germany a maximum in the number of damaging hail events at 13:00 and 18:00 LT. The same peak is found in alpine regions such as Italy (Morgan, 1973) or Switzerland (Nisi et al., 2016), where the maximum hail occurs in the late afternoon and the minimum in the morning, according to radar data analysis.

Lukach et al. (2017) demonstrated for southeast Belgium that hail falls mostly during 15:00-16:00 UTC, which is in accordance to the daily cycle in subdomain BEL that includes Belgium. In this study we found a peak of hail around 16:00 LT in subdomain SWF, while Mallafré et al. (2009) established a peak later in the afternoon at around 18:00 LT. Note that only the hail seasons of years 2004 and 2005 in the Ebro valley were considered in the study by Mallafré et al. (2009).

\subsection{Main characteristics of hail tracks}

In the following section, we explore the main characteristics of our sample of radar-detected hail tracks. The length is defined as the distance in kilometers between the start and the end of a track determined by CCTA2D, i.e., the period where a threshold of $55 \mathrm{dBZ}$ is reached or exceeded. The distribution of the lengths shown in the histogram in Fig. 9 approximately follows an exponential function with a maximum for the first class.

In general, the mean length (with standard deviation) is $41.5 \pm 36.4 \mathrm{~km}$ with a median of $29.5 \mathrm{~km}$ for the entire investigated area. The tracks reconstructed for Germany have a mean length of $39.1 \pm 33 \mathrm{~km}$ and a median of $27 \mathrm{~km}$, whereas in France the mean length is slightly larger with $43.9 \pm 39.8$ and $32 \mathrm{~km}$ for the median. In total, $43 \%$ of all recorded storms over western Europe have a length between 1 and $10 \mathrm{~km}$. The number of tracks having a length between 10 and $20 \mathrm{~km}$ decreases to $19 \%$ of the overall sample. Approximately $30 \%$ of all tracks have a length between 20 and $100 \mathrm{~km}$, and less than $10 \%$ are greater than $100 \mathrm{~km}$ (not

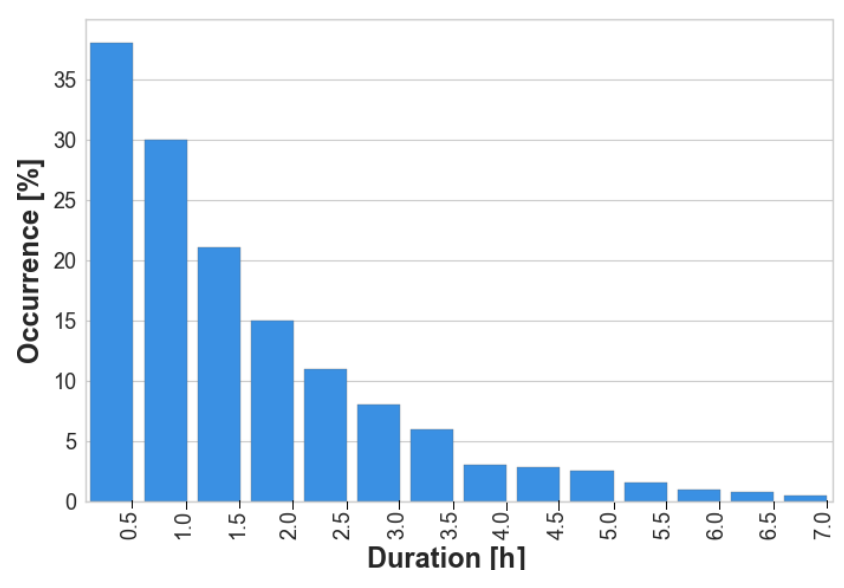

Figure 10. Same as Fig. 9 but for the mean durations.

shown). Longer tracks can be expected for highly organized convective systems, such as MCSs (mesoscale convective storms) or supercells.

Only a few authors have analyzed hail track characteristics in western Europe and there are only very few studies based their investigations over a sufficiently long period. Puskeiler (2013), for example, investigated hail track lengths using 3D radar data in Germany during 2005 and 2011 and found a mean length of $48 \mathrm{~km}$ with a strong decrease for longer streaks, inducing a high standard deviation of $46.7 \mathrm{~km}$ and a median of $40 \mathrm{~km}$. Dessens (1986) found a mean length of $80 \mathrm{~km}$ for a small sample of 30 hailstorms in southwestern France. Note that Dessens (1986) used hail observations related to crop damage from the ANELFA network. For Spain, Mallafré et al. (2009) determined a mean hailstreak length of around $50 \pm 20 \mathrm{~km}$ and used the Storm Cell Identification and Tracking (SCIT) algorithm elaborated by Johnson et al. (1998) on 3D radar data over northern Spain during 2004 and 2005 in order to identify hail cells.

The distribution of the hail track duration (Fig. 10) is in accordance with the length and also decreases almost exponentially with a peak at $30 \mathrm{~min}$. As for the other physical characteristics, long-lived swaths are rare; only $2.4 \%$ of all cells persist over $5 \mathrm{~h}$ (Fluck, 2018). The width, expressed as the maximum diameter of the largest reflectivity core $(Z \geq 55 \mathrm{dBZ})$ during a hailstorm, or the longest distance between two cores evolving laterally in cases of cell merging or splitting, show approximately a Gaussian distribution. The peak is between 9 and $10 \mathrm{~km}$ ( $41 \%$ of all events; not shown).

However, as only the largest width of each swath is recorded, the results may be overestimated. The track angle shown in Fig. 11 represents the mean orientation of a storm track and is the angle recorded by CCTA2D at the center of a swath, as most of the storm tracks are approximately linear. The orientation is defined as the angle between the line intersecting the reflectivity core centers before and after the central point of a swath and the parallel of latitude intersect- 


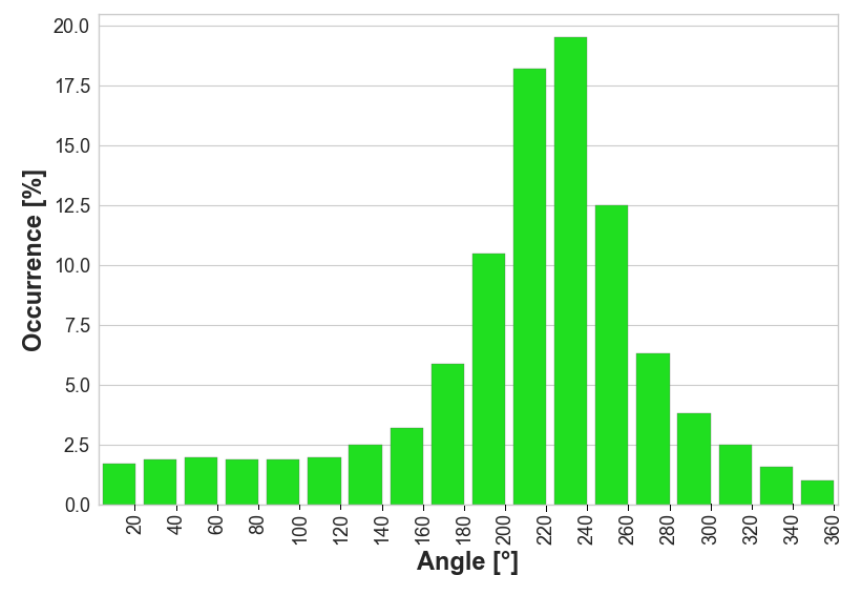

Figure 11. Same as Fig. 10 but for the mean orientations.

ing the start point. With this method, three time steps (i.e., 10 min) must exist for a track to be recorded. The maximum occurrence $(19.3 \%)$ is found in the propagation direction between 220 and $240^{\circ}$, i.e., with a southwest direction. Around half $(51 \%)$ of the hailstorms come from between 200 and $260^{\circ}$. Only $2.8 \%$ of the swaths have a northwesterly direction. The principal southwesterly swath orientation found in the statistics confirmed previous results, such as that in the study by Puskeiler (2013), who found the highest number of hail days in southwest Germany with swaths oriented in southwesterly direction. In the Aquitaine region of France, Berthet et al. (2013) found that between 1952 and 1980 severe hail falls came from a southwesterly direction with a mean angle of $241^{\circ}$.

\section{Conclusions}

This paper presents the first high-resolution, radar-based hail statistics for a large central European region covering the countries of France, Germany, Belgium and Luxembourg over a 10 year period. A European radar composite has been created from French and German national radar composites with a 5 min time step and corrected with lightning data. Tracks of SCSs have been reconstructed using the tracking algorithm CCTA2D. Only grid points exceeding the Mason (1971) criterion for hail ( $Z \geq 55 \mathrm{dBZ}$ ) have been used for the hail assessment. From the spatial analyses of the hail signals, the following main results are obtained:

- The frequency of hailstorms shows a very large spatial variability across the investigation area. In general, there is a coast-to-continental increase in the number of hail days. While only a few radar-derived hail days occurred in the northern parts of Europe (0-2 hail days per year), the number of hail days farther inland is much higher.

- Most of the hail hotspots are found on the leeward side of low-mountain ranges such as the Massif Central in
France or the Black Forest in Germany. The large number of track onsets around orographic structures suggest a strong relationship between hailstorm occurrence and flow conditions induced or invigorated by orography such as a flow-around regime with subsequence flow convergence on the leeward side.

- On the regional scale, some differences in the seasonal and hourly distribution of hail occurrences are found across Europe. In southwest France, for instance, the hail maximum is in mid-June but occurs 2 months later in August in eastern Germany.

Our radar-derived hail frequency estimations and maps have, of course, several limitations and uncertainties. First, due to the local-scale nature of hailstorms and the lack of accurate observations, the reconstructed streaks and their statistics are difficult to validate. No homogeneous monitoring system for hail exists over the entire investigation region, but only some local networks, for example, the hailpad network over southwest, central, and southern France operated by ANELFA, are available. However, hailpad networks do not exist in Belgium, Luxembourg and Germany. Thus, the use of radar and lightning data only provide a proxy for hail occurrence.

Because only 2D radar data were available for this study, more sophisticated hail detection algorithms, such as those based on echo top height (e.g., POH) or vertical integrals of reflectivity (e.g., MESH), which generally show higher skill in hail prediction (e.g., Skripniková and Řezáčová, 2014; Kunz and Kugel, 2015; Puskeiler et al., 2016) could not have been applied. The radar coverage over western Europe is reliable, but several regions are still not or not sufficiently covered by several radars, such as the alpine chain or some areas in the southeastern part of Germany and near Lake Constance. This leads to some data gaps in the final composite.

Despite the abovementioned limitations in our methods, the final results are in good accordance to other studies such as those for Germany based on 3D radar data (Puskeiler, 2013; Puskeiler et al., 2016; Schmidberger, 2018). The spatial distribution of hail signals in our study area is also similar to satellite-estimated hail frequency based on overshooting cloud tops as described by Punge et al. $(2014,2017)$.

The investigations can be improved by extending the observation period until today. This is important especially in the subdomains highly exposed to hail. More accurate detections of hail can be achieved via the use of dual-polarization measurements (Heinselman and Ryzhkov, 2006). Furthermore, detailed investigations of the flow characteristics depending on atmospheric conditions, for example, by using high-resolution numerical weather prediction models, can help to find robust evidence of the flow-around regime that may be decisive for the increased hail frequency downstream of several low mountain ranges and can also contribute to a better understanding of the influence of orography on the triggering of convection. 
Data availability. 2D radar data for Germany can be accessed via the German Weather Service (DWD) ftp server, while French national radar composites are available upon request to the French Meteorological Service (Météo-France). SCSs/hail tracks were computed on radar data and are available upon request to Michael Kunz. ERA5 data can be downloaded from the ECMWF server.

- For the access to 2D radar data (France + Germany): person to contact at the Institute of Meteorology and Climate Research, Karlsruhe Institute of Technology (IMK-TRO, KIT) in Karlsruhe, Germany: Manuel Schmidberger.

- For SCSs/hail tracks: person to contact at the Institute of Meteorology and Climate Research, Karlsruhe Institute of Technology (IMK-TRO, KIT) in Karlsruhe, Germany: Michael Kunz. Head of working group "Atmospheric risks".

- ERA5-Land hourly data are accessible at : https://cds.climate. copernicus.eu/cdsapp\#!/dataset/reanalysis-era5-land?tab= form (last access: 14 February 2021) (CDS, 2021).

Author contributions. EF edited most parts of the paper, performed the statistical analyses and computed the SCSs/hail tracks. MK verified in detail the analytical methods and results, added crucial suggestions to the paper and contributed to the editing and revision of the manuscript. PG and SR added constructive suggestions to the paper. MK supervised the project in collaboration with PG and SR.

Competing interests. The authors declare that they have no conflict of interest.

Acknowledgements. The authors thank the French Meteorological Service (Météo-France) and the German Weather Service (DWD) for providing long-term radar data, and Siemens AG (Stefan Thern) for supplying the lightning data. The authors also acknowledge Tokio Millennium Re Ltd for funding the project. We acknowledge the constructive and very helpful comments from two anonymous reviewers who helped improve the quality of this manuscript.

Financial support. The authors also acknowledge Tokio Millennium Re Ltd for funding the project.

The article processing charges for this open-access publication were covered by a Research Centre of the Helmholtz Association.

Review statement. This paper was edited by Paolo Tarolli and reviewed by two anonymous referees.

\section{References}

Amante, C. and Eakins, B. W.: ETOPO1 arc-minute global relief model: procedures, data sources and analysis, Tech. rep., NOAA, availabel at: https://www.ngdc.noaa.gov/mgg/global/relief/ ETOPO1/docs/ETOPO1.pdf (last access: 14 February 2021), 2009.

Auer, A. H.: Distribution of graupel and hail with size, Mon. Weather Rev., 100, 325-328, 1972.

Augros, C., Tabary, P., Anquez, A., Moisselin, J.-M., Brovelli, P., and Bousquet, O.: Development of a nationwide, low-level wind shear mosaic in France, Weather Forecast., 28, 1241-1260, https://doi.org/10.1175/WAF-D-12-00115.1, 2013.

Bartels, H., Weigl, E., Reich, T., Lang, P., Wagner, A., Kohler, O., and Gerlach, N.: Projekt RADOLAN - Routineverfahren zur Online-Aneichung der Radarniederschlagsdaten mit Hilfe von automatischen Bodenniederschlagsstationen (Ombrometer), Tech. rep., Deutscher Wetterdienst, available at: https://www.dwd.de/DE/leistungen/radolan/radolan_info/ abschlussbericht_pdf.pdf?_blob=publicationFile\&v=2 (last access: 14 February 2021), 2004.

Barthlott, C., Adler, B., Kalthoff, N., Handwerker, J., Kohler, M., and Wieser, A.: The role of Corsica in initiating nocturnal offshore convection, Q. J. Roy. Meteorol. Soc., 142, 222-237, https://doi.org/10.1002/qj.2415, 2016.

Baughman, R. and Fuquay, D.: Hail and lightning occurrence in mountain thunderstorms, J. Appl. Meteorol., $\quad 9, \quad 657-660, \quad$ https://doi.org/10.1175/15200450(1970)009<0657:HALOIM>2.0.CO;2, 1970.

Beck, J. and Bousquet, O.: Using gap-filling radars in mountainous regions to complement a national radar network: Improvements in multiple-Doppler wind syntheses, J. Appl. Meteorol. Clim., 52, 1836-1850, https://doi.org/10.1175/JAMC-D12-0187.1, 2013.

Bedka, K.: Overshooting cloud top detections using MSG SEVIRI Infrared brightness temperatures and their relationship to severe weather over Europe, Atmos. Res., 99, 175-189, https://doi.org/10.1016/j.atmosres.2010.10.001, 2011.

Berthet, C., Dessens, J., and Sanchez, J. L.: Regional and yearly variations of hail frequency and intensity in France, Atmos. Res., 100, 391-400, https://doi.org/10.1016/j.atmosres.2010.10.008, 2011.

Berthet, C., Wesolek, E., Dessens, J., and Sanchez, J. L.: Extreme hail day climatology in Southwestern France, Atmos. Res., 123, 139-150, https://doi.org/10.1016/j.atmosres.2012.10.007, 2013.

Bousquet, O., Tabary, P., and Parent-du Châtelet, J.: Observation opérationnelle du vent $3 \mathrm{D}$ dans les nuagesà partir des radars du réseau Aramis, La Météorologie 61, 41-51, https://doi.org/10.4267/2042/17789, 2008.

Brooks, H. E., Lee, J. W., and Craven, J. P.: The spatial distribution of severe thunderstorm and tornado environments from global reanalysis data, Atmos. Res., 67, 73-94, https://doi.org/10.1016/S0169-8095(03)00045-0, 2003.

Cantat, O.: Analyse critique sur les tendances pluviométriques au 20eme siècle en Basse-Normandie: Réfléxions sur la fiabilité des données et le changement climatique, Climatologie, 1, 11-32, https://doi.org/10.4267/climatologie.963, 2004.

CDS: ERA5-Land hourly data from 1981 to present, available at: https://cds.climate.copernicus.eu/cdsapp\#!/dataset/ reanalysis-era5-land?tab=form, last access: 14 February 2021. 
Chaboureau, J.-P., Chédin, A., and Scott, N. A.: Relationship between sea surface temperature, vertical dynamics, and the vertical distribution of atmospheric water vapor inferred from TOVS observations, Geophys. Res., 103, 23173-23180, https://doi.org/10.1029/98JD02019, 1998.

Champeaux, J., Laurantin, O., Mercier, B., Mounier, F., Lassegues, P., and Tabary, P.: Quantitative precipitation estimations using rain gauges and radar networks: inventory and prospects at Meteo-France, in: WMO Joint Meeting of CGS Expert Team on Surface-based Remotely-sensed Observations and CIMO Expert Team on Operational Remote Sensing, vol. 5, 1-11, available at: https://www.wmo.int/pages/prog/www/ OSY/Meetings/ET-SBRSO_ET-RSO-2011/DocPlan/INF.3.3.

2_Report_METEOFRANCE_QPE.pdf (last access: 14 February 2021), 2011.

Changnon, S. A.: The scales of hail, J. Appl. Meteorol., 16, 626-648, https://doi.org/10.1175/15200450(1977)016<0626:TSOH>2.0.CO;2, 1977.

Changnon, S. A.: Data and approaches for determining hail risk in the contiguous United States, J. Appl. Meteorol., 38, 1730-1739, https://doi.org/10.1175/15200450(1999)038<1730:DAAFDH>2.0.CO;2, 1999.

Cintineo, J. L., Smith, T. M., Lakshmanan, V., Brooks, H. E., and Ortega, K. L.: An objective high-resolution hail climatology of the contiguous United States, Weather Forecast., 27, 1235-1248, https://doi.org/10.1175/WAF-D-11-00151.1, 2012.

Dee, D., Uppala, S., Simmons, A., Berrisford, P., Poli, P., Kobayashi, S., Andrae, U., Balmaseda, M., Balsamo, G., Bauer, P., Bechtold, P., Beljaars, A. C. M., van der Berg, L., Bidlot, J., Bormann, N., Delsol, C., Dragani, R., Fuentes, M., Geer, A. J., Haimberger, L., Healy, S. B., Hersbach, H., Hólm, E. V., Isaksen, L., Kållberg, P., Köhler, M., Matricardi, M., McNally, A. P., Monge-Sanz, B. M., Morcrette, J.-J., Park, B.-K., Peubey, C., de Rosnay, P., Tavolato, C., Thépaut, J.-N., and Vitart, F.: The ERA-Interim reanalysis: Configuration and performance of the data assimilation system, Q. J. Roy. Meteorol. Soc., 137, 553597, 2011.

Deepen, J.: Schadenmodellierung extremer Hagelereignisse in Deutschland, MS thesis, Institut für Landschaftsökologie der Westfälischen Wilhelms-Universität Münster, Münster, Germany, available at: https://www.uni-muenster.de/imperia/md/ content/landschaftsoekologie/klima/pdf/2006_deepen_dipl.pdf (last access: 14 February 2021), 2006.

Dessens, J.: Hail in Southwestern France. I: Hailfall Characteristics and Hailstrom Environment, J. Clim. Appl. Meteorol., 25, 35-47, https://doi.org/10.1175/15200450(1986)025<0035:HISFIH>2.0.CO;2, 1986.

Dessens, J., Berthet, C., and Sanchez, J.: Change in hailstone size distributions with an increase in the melting level height, Atmos. Res., 158, 245-253, https://doi.org/10.1016/j.atmosres.2014.07.004, 2015.

DeutscheRück: Sturmdokumentation 2012 Deutschland, Tech. rep., Deutsche Rückversicherung, available at: https://www.deutscherueck.de/fileadmin/user_upload/WEB_ Sturmdoku_2012.pdf (last access: 14 February 2021), 2013.

Dotzek, N., Groenemeijer, P., Feuerstein, B., and Holzer, A. M.: Overview of ESSL's severe convective storms research using the European Severe Weather Database ESWD, Atmos. Res., 93, 575-586, https://doi.org/10.1016/j.atmosres.2008.10.020, 2009.
Doviak, R. J. and Zrnić, D. S.: Doppler radar and weather observations, Courier Corporation, Mineola, New York, 2006.

Eccel, E., Cau, P., Riemann-Campe, K., and Biasioli, F.: Quantitative hail monitoring in an alpine area: 35-year climatology and links with atmospheric variables, Int. J. Climatol., 32, 503-517, 2012.

Figueras i Ventura, J. and Tabary, P.: The new French operational polarimetric radar rainfall rate product, J. Appl. Meteorol. Clim., 52, 1817-1835, https://doi.org/10.1175/JAMC-D-120179.1, 2013.

Figueras i Ventura, J., Boumahmoud, A.-A., Fradon, B., Dupuy, P., and Tabary, P.: Long-term monitoring of French polarimetric radar data quality and evaluation of several polarimetric quantitative precipitation estimators in ideal conditions for operational implementation at C-band, Q. J. Roy. Meteorol. Soc., 138, 2212 2228, https://doi.org/10.1002/qj.1934, 2012.

Fluck, E.: Hail statistics for European countries, $\mathrm{PhD}$ thesis, Karlsruhe Institute of Technology, Karlsruhe, Germany, available at: https://pdfs.semanticscholar.org/74b5/ 2e00fd4d299e40011d73aa596c6846212252.pdf (last access: 14 February 2021), 2018.

Fouillet, A., Rey, G., Wagner, V., Laaidi, K., Empereur-Bissonnet, P., Le Tertre, A., Frayssinet, P., Bessemoulin, P., Laurent, F., De Crouy-Chanel, P., et al.: Has the impact of heat waves on mortality changed in France since the European heat wave of summer 2003? A study of the 2006 heat wave, Int. J. Epidemiol., 37, 309-317, https://doi.org/10.1093/ije/dym253, 2008.

Fraile, R., Castro, A., and Sánchez, J. L.: Analysis of hailstone size distributions from a hailpad network, Atmos. Res., 28, 311-326, https://doi.org/10.1016/0169-8095(92)90015-3, 1992.

Fraile, R., Berthet, C., Dessens, J., and Sánchez, J. L.: Return periods of severe hailfalls computed from hailpad data, Atmos. Res., 67, 189-202, https://doi.org/10.1016/S0169-8095(03)00051-6, 2003.

Gregg, W. and Tannehill, I.: International standard projections for meteorological charts, Mon. Weather Rev., 65, 411-415, 1937.

Gudd, M.: Gewitter und Gewitterschäden im südlichen hessischen Berg-und Beckenland und im Rhein-Main-Tiefland 1881 bis 1980: eine Auswertung mit Hilfe von Schadensdaten, $\mathrm{PhD}$ thesis, University of Mainz, Mainz, Germany, available at: https://openscience.ub.uni-mainz.de/handle/20.500.12030/3428 (last access: 14 February 2021), 2003.

Handwerker, J.: Cell Tracking with TRACE3D: a New Algorithm, Atmos. Res., 61, 15-34, https://doi.org/10.1016/S01698095(01)00100-4, 2002.

Heinselman, P. L. and Ryzhkov, A. V.: Validation of polarimetric hail detection, Weather Forecast., 21, 839-850, https://doi.org/10.1175/WAF956.1, 2006.

Hermida, L., Sánchez, J. L., López, L., Berthet, C., Dessens, J., García-Ortega, E., and Merino, A.: Climatic trends in hail precipitation in France: spatial, altitudinal, and temporal variability, Sci. World J., 2013, 494971, https://doi.org/10.1155/2013/494971, 2013.

Hermida, L., López, L., Merino, A., Berthet, C., GarcíaOrtega, E., Sánchez, J. L., and Dessens, J.: Hailfall in Southwest France: Relationship with precipitation, trends and wavelet analysis, Atmos. Res., 156, 174-188, https://doi.org/10.1016/j.atmosres.2015.01.005, 2015. 
Hersbach, H., Bell, B., Berrisford, P., Hirahara, S., Horányi, A., Muñoz-Sabater, J., Nicolas, J., Peubey, C., Radu, R., Schepers, D., and Simmons, A.: The ERA5 global reanalysis, Q. J. Roy. Meteorol. Soc., 146, 1999-2049, https://doi.org/10.1002/qj.3803, 2020.

Hohl, R.: Relationship between hailfall intensity and hail damage on ground, determined by radar and lightning observations, $\mathrm{PhD}$ hesis, Departement of Geography, University of Fribourg, Fribourg, Switzerland, available at: https://doc.rero.ch/record/5136/ files/1_HohlRM.pdf (last access: 14 February 2021), 2001.

Hohl, R., Schiesser, H.-H., and Aller, D.: Hailfall: the relationship between radar-derived hail kinetic energy and hail damage to buildings, Atmos. Res., 63, 177-207, https://doi.org/10.1016/S0169-8095(02)00059-5, 2002.

Houze J, R. A.: Cloud dynamics, Academic Press, available at: https://www.sciencedirect.com/bookseries/ international-geophysics/vol/104/suppl/C (last access: 14 February 2021), 2014.

Jenkner, J., Sprenger, M., Schwenk, I., Schwierz, C., Dierer, S., and Leuenberger, D.: Detection and climatology of fronts in a highresolution model reanalysis over the Alps, Q. J. Roy. Meteorol. Soc., 17, 1-18, https://doi.org/10.1002/met.142, 2010.

Johnson, A. W. and Sugden, K. E.: Evaluation of sounding-derived thermodynamic and wind-related parameters associated with large hail events, Electron. J. Severe Storms Metereol., 9, 1-42, 2014.

Johnson, J., MacKeen, P. L., Witt, A., Mitchell, E. D. W., Stumpf, G. J., Eilts, M. D., and Thomas, K. W.: The storm cell identification and tracking algorithm: An enhanced WSR-88D algorithm, Weather Forecast., 13, 263-276, https://doi.org/10.1175/15200434(1998)013<0263:TSCIAT>2.0.CO;2, 1998.

Junghänel, T., Brendel, C., Winterrath, T., and Walter, A.: Towards a radar- and observation-based hail climatology for Germany, Meteorol. Z., 25, 435-445, https://doi.org/10.1127/metz/2016/0734, 2016.

Kaltenböck, R., Diendorfer, G., and Dotzek, N.: Evaluation of thunderstorm indices from ECMWF analyses, lightning data and severe storm reports, Atmos. Res., 93, 381-396, https://doi.org/10.1016/j.atmosres.2008.11.005, 2009.

Kirshbaum, D. J., Adler, B., Kalthoff, N., Barthlott, C., and Serafin, S.: Moist orographic convection: Physical mechanisms and links to surface-exchange processes, Atmosphere, 9, 80, https://doi.org/10.3390/atmos9030080, 2018.

Koebele, D.: Analyse von Konvergenzbereichen bei Hagelereignissen stromab von Mittelgebirgen anhand von COSMOModellsimulationen, MS thesis, Karlsruhe Institute of Technology, Karlsruhe, Germany, available at: https://www.imk-tro.kit. edu/download/Masterarbeit_Koebele.pdf (last access: 14 February 2021), 2014.

Kreklow, J., Tetzlaff, B., Burkhard, B., and Kuhnt, G.: RadarBased Precipitation Climatology in Germany - Developments, Uncertainties and Potentials, Atmosphere, 11, 217, https://doi.org/10.3390/atmos11020217, 2020.

Kunz, M.: The skill of convective parameters and indices to predict isolated and severe thunderstorms, Nat. Hazards Earth Syst. Sci., 7, 327-342, https://doi.org/10.5194/nhess-7-327-2007, 2007.

Kunz, M. and Kugel, P. I.: Detection of hail signatures from singlepolarization C-band radar reflectivity, Atmos. Res., 153, 565577, https://doi.org/10.1016/j.atmosres.2014.09.010, 2015.
Kunz, M. and Puskeiler, M.: High-resolution Assessment of the Hail Hazard over Complex Terrain from Radar and Insurance Data, Meteorol. Z., 19, 427-439, https://doi.org/10.1127/09412948/2010/0452, 2010.

Kunz, M., Blahak, U., Handwerker, J., Schmidberger, M., Punge, H. J., Mohr, S., Fluck, E., and Bedka, K. M.: The severe hailstorm in SW Germany on 28 July 2013: Characteristics, impacts, and meteorological conditions, Q. J. Roy. Meteorol. Soc., 144, 231250, https://doi.org/10.1002/qj.3197, 2018.

Kunz, M., Wandel, J., Fluck, E., Baumstark, S., Mohr, S., and Schemm, S.: Ambient conditions prevailing during hail events in central Europe, Nat. Hazards Earth Syst. Sci., 20, 1867-1887, https://doi.org/10.5194/nhess-20-1867-2020, 2020.

Langhans, W., Schmidli, J., Fuhrer, O., Bieri, S., and Schär, C.: Long-term simulations of thermally driven flows and orographic convection at convection-parameterizing and cloud-resolving resolutions, J. Appl. Meteorol., 52, 1490-1510, 2013.

Lenderink, G., Van Meijgaard, E., and Selten, F.: Intense coastal rainfall in the Netherlands in response to high sea surface temperatures: analysis of the event of August 2006 from the perspective of a changing climate, Clim. Dynam., 32, 19-33, https://doi.org/10.1007/s00382-008-0366-x, 2009.

Lukach, M. and Delobbe, L.: Radar-based hail statistics over Belgium, in: 7th European Conference on Severe Storms (ECSS), 7-13 June 2013, Helsinki, Finland, 2013.

Lukach, M., Foresti, L., Giot, O., and Delobbe, L.: Estimating the occurrence and severity of hail based on 10 years of observations from weather radar in Belgium, Meteorol. Appl., 24, 250-259, https://doi.org/10.1002/met.1623, 2017.

Mallafré, M. C., Ribas, T. R., del Carmen Llasat Botija, M., and Sánchez, J. L.: Improving hail identification in the Ebro Valley region using radar observations: Probability equations and warning thresholds, Atmos. Res., 93, 474-482, https://doi.org/10.1016/j.atmosres.2008.09.039, 2009.

Markowski, P. and Richardson, Y.: Mesoscale meteorology in midlatitudes, vol. 3, John Wiley, available at: https:// onlinelibrary.wiley.com/doi/book/10.1002/9780470682104 (last access: 14 February 2021), 2010.

Mason, B.: The physics of clouds, Oxford University Press, Oxford, https://doi.org/10.1002/qj.49709841723, 1971.

Mass, C.: Topographically forced convergence in western Washington State, Mon. Weather Rev., 109, 1335-1347, https://doi.org/10.1175/15200493(1981)109<1335:TFCIWW>2.0.CO;2, 1981.

Merino, A., García-Ortega, E., López, L., Sánchez, J., and Guerrero-Higueras, A.: Synoptic environment, mesoscale configurations and forecast parameters for hailstorms in Southwestern Europe, Atmos. Res., 122, 183-198, https://doi.org/10.1016/j.atmosres.2012.10.021, 2013.

Mohr, S. and Kunz, M.: Recent trends and variabilities of convective parameters relevant for hail events in Germany and Europe, Atmos. Res., 123, 211-228, https://doi.org/10.1016/j.atmosres.2012.05.016, 2013.

Mohr, S., Kunz, M., and Geyer, B.: Hail potential in Europe based on a regional climate model hindcast, Geophys. Res. Lett., 42, 10904-10912, https://doi.org/10.1002/2015GL067118, 2015a.

Mohr, S., Kunz, M., and Keuler, K.: Development and application of a logistic model to estimate the past and future 
hail potential in Germany, J. Geophys. Res., 120, 3939-3956, https://doi.org/10.1002/2014JD022959, 2015b.

Mohr, S., Wandel, J., Lenggenhager, S., and Martius, O.: Relationship between atmospheric blocking and warm-season thunderstorms over western and central Europe, Q. J. Roy. Meteorol. Soc., 145, 3040-3056, https://doi.org/10.1002/qj.3603, 2019.

Morgan, G. M.: A general description of the hail problem in the Po Valley of northern Italy, J. Appl. Meteorol., $\quad 12, \quad 338-353, \quad$ https://doi.org/10.1175/15200450(1973)012<0338:AGDOTH>2.0.CO;2, 1973.

Nesbitt, S. W. and Zipser, E. J.: The diurnal cycle of rainfall and convective intensity according to three years of TRMM measurements, J. Climate, 16, 1456-1475, https://doi.org/10.1175/15200442(2003)016<1456:TDCORA >2.0.CO;2, 2003.

Nisi, L., Ambrosetti, P., and Clementi, L.: Nowcasting severe convection in the Alpine region: The COALITION approach, Q. J. Roy. Meteorol. Soc., 140, 1684-1699, https://doi.org/10.1002/qj.2249, 2014.

Nisi, L., Martius, O., Hering, A., Kunz, M., and Germann, U.: Spatial and temporal distribution of hailstorms in the Alpine region: a long-term, high resolution, radar-based analysis, Q. J. Roy. Meteorol. Soc., 142, 1590-1604, https://doi.org/10.1002/qj.2771, 2016.

Nisi, L., Hering, A., Germann, U., and Martius, O.: A 15-year hail streak climatology for the Alpine region, Q. J. Roy. Meteorol. Soc., 144, 1429-1449, https://doi.org/10.1002/qj.3286, 2018.

NOAA: Global Climate Report for Annual 2006, Tech. rep., NOAA National Centers for Environmental Information, available at: https://www.ncdc.noaa.gov/sotc/global/200713 (last access: 14 February 2021), 2007.

NOAA: Global Climate Report for Annual 2010, Tech. rep., National Centers for Environmental Information, available at: https: //www.ncdc.noaa.gov/sotc/global/201013 (last access: 14 February 2021), 2011.

Pilorz, W. and Łupikasza, E.: Radar reflectivity signatures and possible lead times of warnings for very large hail in Poland based on data from 2007-2015, Environ. Soc. Econ. Stud., 8, 34-47, https://doi.org/10.2478/environ-2020-0016, 2020.

Piper, D. and Kunz, M.: Spatiotemporal variability of lightning activity in Europe and the relation to the North Atlantic Oscillation teleconnection pattern, Nat. Hazards Earth Syst. Sci., 17, 13191336, https://doi.org/10.5194/nhess-17-1319-2017, 2017.

Piper, D. A.: Untersuchung der Gewitteraktivität und der relevanten großräumigen Steuerungsmechanismen über Mittel- und Westeuropa, PhD thesis, Karlsruhe Institute of Technology, Karlsruhe, Germany, https://doi.org/10.5445/KSP/1000072089, 2017.

Piper, D. A., Kunz, M., Allen, J. T., and Mohr, S.: Investigation of the temporal variability of thunderstorms in Central and Western Europe and the relation to large-scale flow and teleconnection patterns, Q. J. Roy. Meteorol. Soc., 145, 3644-3666, https://doi.org/10.1002/qj.3647, 2019.

Pohjola, H. and Mäkelä, A.: The comparison of GLD360 and EUCLID lightning location systems in Europe, Atmos. Res., 123, 117-128, https://doi.org/10.1016/j.atmosres.2012.10.019, 2013.

Punge, H. and Kunz, M.: Hail observations and hailstorm characteristics in Europe: A review, Atmos. Res., 176, 159-184, https://doi.org/10.1016/j.atmosres.2016.02.012, 2016.
Punge, H., Bedka, K., Kunz, M., and Werner, A.: A new physically based stochastic event catalog for hail in Europe, Nat. Hazards, 73, 1625-1645, https://doi.org/10.1007/s11069-014-11610, 2014.

Punge, H., Bedka, K., Kunz, M., and Reinbold, A.: Hail frequency estimation across Europe based on a combination of overshooting top detections and the ERA-INTERIM reanalysis, Atmos. Res., 198, 34-43, https://doi.org/10.1016/j.atmosres.2017.07.025, 2017.

Puskeiler, M.: Radarbasierte Analyse der Hagelgefährdung in Deutschland, $\mathrm{PhD}$ thesis, Karlsruhe Institute of Technology, Karlsruhe, Germany, available at: http://www.imk-tro. kit.edu/download/Dissertation_Puskeiler_Marc.pdf (last access: 14 February 2021), 2013.

Puskeiler, M., Kunz, M., and Schmidberger, M.: Hail statistics for Germany derived from singlepolarization radar data, Atmos. Res., 178, 459-470, https://doi.org/10.1016/j.atmosres.2016.04.014, 2016.

Queney, P.: The problem of air flow over mountains: A summary of theoretical studies, B. Am. Meteorol. Soc., 29, 16-26, https://doi.org/10.1175/1520-0477-29.1.16, 1948.

Rädler, A. T., Groenemeijer, P., Faust, E., and Sausen, R.: Detecting Severe Weather Trends Using an Additive Regressive Convective Hazard Model (AR-CHaMo), J. Appl. Meteorol., 57, 569-587, https://doi.org/10.1175/JAMC-D-17-0132.1, 2018.

Schemm, S., Nisi, L., Martinov, A., Leuenberger, D., and Martius, O.: On the link between cold fronts and hail in Switzerland, Atmos. Sci. Lett, 17, 315-325, 2016.

Schmidberger, M.: Hagelgefährdung und Hagelrisiko in Deutschland basierend auf einer Kombination von Radardaten und Versicherungsdaten, $\mathrm{PhD}$ thesis, Karlsruhe Institute of Technology, Karlsruhe, Germany, https://doi.org/10.5445/KSP/1000086012, 2018.

Schulz, W., Diendorfer, G., Pedeboy, S., and Poelman, D. R.: The European lightning location system EUCLID - Part 1: Performance analysis and validation, Nat. Hazards Earth Syst. Sci., 16, 595-605, https://doi.org/10.5194/nhess-16-595-2016, 2016.

Schuster, S. S., Blong, R. J., and Speer, M. S.: A hail climatology of the greater Sydney area and New South Wales, Australia, Int. J. Climatol., 25, https://doi.org/10.1002/joc.1199, 2005.

Skripniková, K. and Řezáčová, D.: Radar-based hail detection, Atmos. Res., 144, 175-185, https://doi.org/10.1016/j.atmosres.2013.06.002, 2014.

Smith, B. T., Thompson, R. L., Grams, J. S., Broyles, C., and Brooks, H. E.: Convective modes for significant severe thunderstorms in the contiguous United States. Part I: Storm classification and climatology, Weather Forecast., 27, 1114-1135, https://doi.org/10.1175/WAF-D-11-00115.1, 2012.

Smith, R. B.: The influence of mountains on the atmosphere, in: Advances in Geophysics, vol. 21, Elsevier, New York, 87-230, 1979.

Smolarkiewicz, P. K. and Rotunno, R.: Low Froude number flow past three-dimensional obstacles. Part I: Baroclinically generated lee vortices, J. Atmos. Sci., 46, 1154-1164, https://doi.org/10.1175/15200469(1989)046<1154:LFNFPT>2.0.CO;2, 1989.

Steiner, M. and Smith, J. A.: Use of three-dimensional reflectivity structure for automated detection and removal of nonprecipitating echoes in radar data, J. Atmos. 
Ocean. Tech., 19, 673-686, https://doi.org/10.1175/15200426(2002)019<0673:UOTDRS>2.0.CO;2, 2002.

Steppeler, J., Doms, G., Schättler, U., Bitzer, H. W., Gassmann, A., Damrath, U., and Gregoric, G.: Meso-gamma scale forecasts using the nonhydrostatic model LM, Meteorol. Atmos. Phys., 82, 75-96, https://doi.org/10.1007/s00703-001-0592-9, 2003.

SwissRe: Sigma: Natural- and Man-made Catastrophes 2013, Tech. rep., Swiss Re Economic Research and Consulting, available at: https://reliefweb.int/sites/reliefweb.int/files/resources/ SwisRe_2014_Natural_Catastrophes_sigma1_2014_en.pdf (last access: 14 February 2021), 2014.

Tabary, P.: The new French operational radar rainfall product. Part I: Methodology, Weather Forecast., 22, 393-408, https://doi.org/10.1175/WAF1004.1, 2007.

Tabary, P., Guibert, F., Perier, L., and Parent-du Chatelet, J.: An operational triple-PRT Doppler scheme for the French radar network, J. Atmos. Ocean. Tech., 23, 1645-1656, https://doi.org/10.1175/JTECH1923.1, 2006.

Tabary, P., Augros, C., Champeaux, J.-L., Chèze, J.-L., Faure, D., Idziorek, D., Lorandel, R., Urban, B., and Vogt, V.: Le réseau et les produits radars de Météo-France, La Météorologie, 83, 1527, https://doi.org/10.4267/2042/52050, 2013.

Taszarek, M., Brooks, H. E., and Czernecki, B.: Sounding-derived parameters associated with convective hazards in Europe, Mon. Weather Rev., 145, 1511-1528, https://doi.org/10.1175/MWRD-16-0384.1, 2017.

Varga, J.: The Lambert conformal conic projection, Period. Polytech. Civ. Eng., 34, 153-158, 1990.
Vinet, F.: Climatology of hail in France, Atmos. Res., 56, 309-323, https://doi.org/10.1016/S0169-8095(00)00082-X, 2001.

Vinet, F.: La question du risque climatique en agriculture: le cas de la grêle en France/Climatic risk in agriculture: the case of hail falls in France, Ann. Geogr., 627-628, 592-613, 2002.

Waldvogel, A., Federer, B., and Grimm, P.: Criteria for the detection of hail cells, J. Appl Meteorol., $\quad 18, \quad 12, \quad$ https://doi.org/10.1175/1520 0450(1979)018<1521:CFTDOH > 2.0.CO;2, 1979.

Wapler, K.: The life-cycle of hailstorms: Lightning, radar reflectivity and rotation characteristics, Atmos. Res., 193, 60-72, https://doi.org/10.1016/j.atmosres.2017.04.009, 2017.

Wapler, K., Hengstebeck, T., and Groenemeijer, P.: Mesocyclones in Central Europe as seen by radar, Atmos. Res., 168, 112-120, https://doi.org/10.1016/j.atmosres.2015.08.023, 2016.

Warren, R. A., Ramsay, H. A., Siems, S. T., Manton, M. J., Peter, J. R., Protat, A., and Pillalamarri, A.: Radar-based climatology of damaging hailstorms in Brisbane and Sydney, Australia, Q. J. Roy. Meteorol. Soc., 146, 505-530, https://doi.org/10.1002/qj.3693, 2020.

Wernli, H., Pfahl, S., Trentmann, J., and Zimmer, M.: How representative were the meteorological conditions during the COPS field experiment in summer 2007?, Meteorol. Z, 19, 619-630, https://doi.org/10.1127/0941-2948/2010/0483, 2010.

Yu, N., Gaussiat, N., and Tabary, P.: Polarimetric X-band weather radars for quantitative precipitation estimation in mountainous regions, Q. J. Roy. Meteorol. Soc., 144, 2603-2619, https://doi.org/10.1002/qj.3366, 2018. 